Rita de Cássia Borges de Castro

\title{
Efeito do ácido docosahexaenoico (DHA) sobre eventos epigenéticos em diferentes linhagens de câncer de mama
}

Dissertação apresentada à Faculdade de Medicina da Universidade de São Paulo para obtenção do título de Mestre em Ciências

Programa de: Oncologia

Orientador: Prof. Dr. Dan Linetzky Waitzberg

São Paulo

2013 
Dados Internacionais de Catalogação na Publicação (CIP)

Preparada pela Biblioteca da

Faculdade de Medicina da Universidade de São Paulo

Creprodução autorizada pelo autor

Castro, Rita de Cássia Borges de

Efeito do ácido docosahexaenoico (DHA) sobre eventos epigenéticos em diferentes linhagens de câncer de mama / Rita de Cássia Borges de Castro. São Paulo, 2013.

Dissertação(mestrado)--Faculdade de Medicina da Universidade de São Paulo. Programa de Oncologia.

Orientador: Dan Linetzky Waitzberg.

Descritores: 1.Ácidos graxos ômega-3 2.Ácidos docosa-hexaenoicos 3.Neoplasias da mama 4.Metilação de DNA 5.Repressão epigenética 6.Histonas 7.Acetilação/efeitos de drogas 8.Regulação neoplásica da expressão gênica 9.Nutrigenômica 10.Anticarcinógenos/farmacologia 11.Linhagem celular tumoral 12.Nutrição

USP/FM/DBD-217/13 


\section{Dedicatória}

$\grave{A}$ Deus,

Aos meus pais Raymundo e Dorinha, Ao meu grande amor Pedro Diego, À minha companheira e amiga desta longa jornada Danielle Fontes. 


\section{Agradecimentos}

À Deus por sempre me conceder bênçãos que me fizeram enfrentar os obstáculos e chegar até aqui;

Ao meu pai Raymundo que tanto me inspirou e me apoiou para ser

uma boa profissional, sei que hoje está aplaudindo com orgulho minha vitória, na casa de Deus. O meu eterno obrigada!

À minha mãe, Dorinha, que está sempre presente e que soube me mostrar o quanto vale a pena viver com honestidade, respeito, dignidade e amor.

Aos meus irmãos queridos, Rafa e Neto, e minhas cunhadas Roslainy e Estela, pela confiança e torcida.

À Pedro Diego, meu grande amor, que em nosso relacionamento sempre prezou pelo respeito, verdade e cumplicidade. Agradeço por me fortalecer nos obstáculos vividos nesse tempo e por acreditar que o nosso amor pode ultrapassar qualquer barreira de tempo e distância.

À Dani (Danielle Fontes de Almeida), amiga, parceira de trabalho e um dos melhores tesouros que pude ganhar com o mestrado. Não tenho palavras para agradecer tudo o que tem feito por mim.

À todos os meus amigos de longa data e da graduação da Universidade Potiguar que tanto me apoiaram e me incentivaram para a minha vinda à São Paulo.

Às nutricionistas do Hospital da Liga Contra o Câncer, com quem tive o prazer em aprimorar meus conhecimentos e continuar com colaborações científicas. Em especial, à Nutricionista Amélia Marques, por ter sido uma grande apoiadora da minha mudança à São Paulo.

Aos colegas do laboratório Metanutri pelos momentos de enriquecimento científico e colaboração. Em especial, Priscila Garla, pelo companheirismo, força e apoio nos momentos difíceis. 
À Karina Al Assal, profissional incrível que tenho muito orgulho de ser amiga. Você que tanto me inspirou e me ensina sobre a prática clínica. Ainda tenho muito que aprender com você.

Ao laboratório de oncologia experimental, LIM 24, grupo mama, por toda dedicação e companheirismo. Em especial, Paulo Roberto Del Valle, Simone Fernandes, Tatiane Furuya e Rosimeire Aparecida Roela.

Ao laboratório do grupo de Adesão Celular, do Prof. Roger Chammas por toda ajuda durante esse percurso.

A todos do laboratório Dieta, Nutrição e Câncer, sem vocês esse trabalho não teria sido possível acontecer.

À Aline De Conti, por ter acreditado e confiado em mim e nesse trabalho, e por todo o aprendizado, discussões científicas. Não tenho palavras para descrever o quanto você foi importante nesta jornada.

À Juliana Miranda, parceirona de experimentos e de aprendizado. A convivência com você tornaram as coisas mais felizes e me deixaram a certeza de que podemos construir boas amizades em momentos tão difíceis.

Ao professor Fernando Salvador Moreno por ter me acolhido no laboratório Dieta, Nutrição e Câncer. Agradeço imensamente as discussões e colaborações científicas. Foi um enorme prazer fazer parte do seu grupo.

Ao professor Thomas Prates Ong, por também ter acreditado nesse trabalho, pelas discussões e colaborações que contribuíram não só para a realização deste estudo, mas também para a minha formação acadêmica.

À professora Maria Mitzi Brentani por todo auxílio na condução e elaboração deste trabalho, além de permitir o uso de seu laboratório para execução dos experimentos.

À professora Ângela Flávia Logullo Waitzberg por toda atenção e colaboração na interpretação dos resultados e nos ensinamentos sobre o câncer de mama. 
Ao meu orientador, mentor e exemplo de profissional, o professor Dan Linetzky Waitzberg. Sem o seu apoio e consentimento nada disso seria possível. Agradeço por toda atenção, paciência e momentos incríveis de intenso aprendizado. Agradeço especialmente por ter confiado e acreditado no meu potencial. Serei eternamente grata por todas as oportunidades a mim oferecidas. Ainda teremos muito trabalho e parcerias pela frente, não quero deixar nunca de aprender com você.

Enfim, a todos vocês e tantos outros colegas, a minha gratidão e que Deus na sua infinita bondade, retribua a vocês em dobro todos os gestos de carinho e amizade que dedicaram a mim. 
"Por vezes sentimos que aquilo que fazemos não é senão uma gota de água no mar. Mas o mar seria menor se the faltasse uma gota". Madre Teresa de Calcutá 


\section{SUMÁRIO}

Lista de abreviaturas e siglas

Lista de figuras

Resumo

Summary

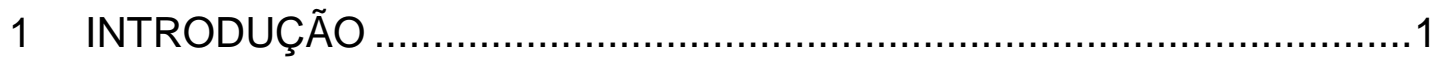

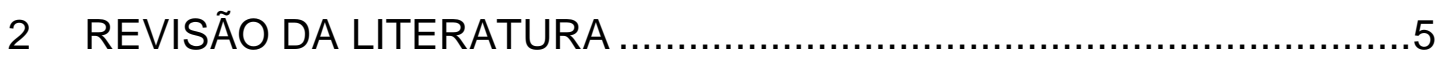

2.1 Câncer, epigenética e nutrição.............................................6

2.1.1 Modificações pós traducionais em histonas .......................8

2.1 .2 Metilação do DNA .................................................. 9

2.1.3 O papel dos nutrientes em modificações pós traducionais em histonas e na metilação do DNA ...............11

2.2 Alterações epigenéticas no câncer de mama ...........................13

2.3 Ácidos graxos ômega-3 e sua relação com o câncer de mama ........15

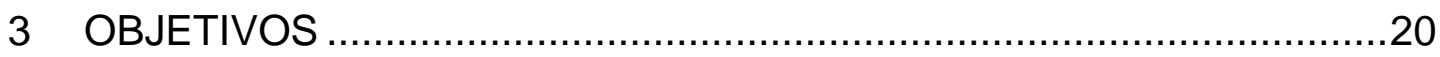

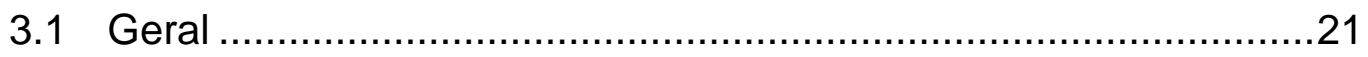

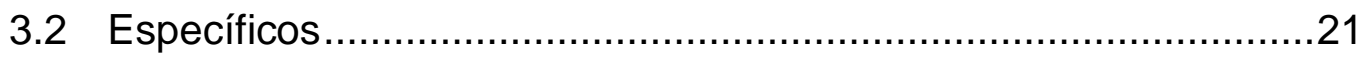

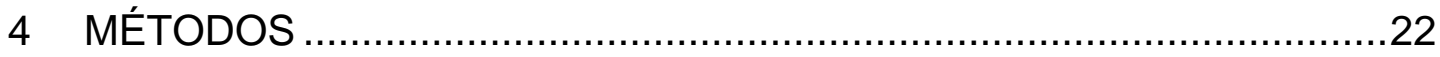

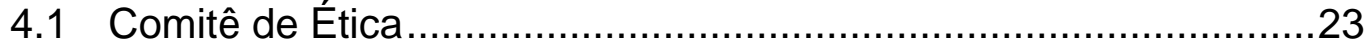

4.2 Cultura Celular ......................................................................23

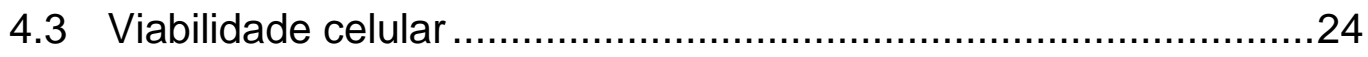

4.4 Tratamento das linhagens com ácido docosahexaenoico (DHA)...24

4.5 Avaliação das modificações pós traducionais em histonas............25

4.6 Análise da expressão gênica por PCR em tempo real do gene RASSF1A.

4.7 Análise do Padrão de Metilação do Promotor do Gene RASSF1A pela Técnica da Reação em Cadeia da Polimerase Específica para Metilação (MS-PCR) ........................................29

4.8 Ensaio de morte e ciclo celular ...........................................31 
5 RESULTADOS

5.1 Acetilação no resíduo de lisina 9 da histona 3 (H3K9ac) e no resíduo 16 da histona 4 (H4K16ac)

5.2 Trimetilação no resíduo de lisina 9 da histona 3 (H3K9me3) e no resíduo 27 da histona 3 (H3K27me3) ...................................36

5.3 Expressão do gene RASSF1A por RT-qPCR ……......................38

5.4 Padrão de Metilação do Promotor do Gene RASSF1A...................39

5.5 Expressão dos genes DNMT1, DNMT3A e DNMT3B por RT-qPCR ..40

5.6 Morte e ciclo celular

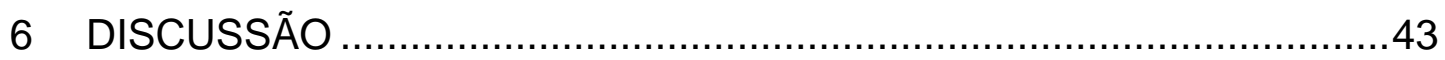

7 CONCLUSÃO

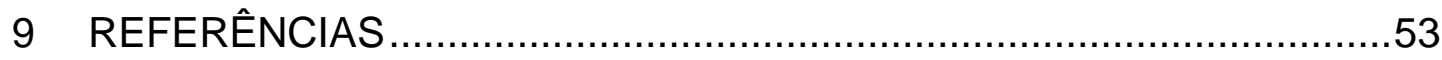




\section{Lista de abreviaturas e siglas}

$\begin{array}{ll}{ }^{\circ} \mathrm{C} & \text { Graus celsius } \\ \mu \mathrm{g} & \text { Microgramas } \\ \mu \mathrm{I} & \text { Microlitros } \\ \mu \mathrm{M} & \text { Micromolar } \\ \text { AGCC } & \text { Ácidos graxos de cadeia curta } \\ \text { AGCL } & \text { Ácidos graxos de cadeia longa } \\ \text { AGCM } & \text { Ácidos graxos de cadeia média } \\ \text { AGPI } & \text { AG poli-insaturados } \\ \text { AGPI n-3 } & \text { Ácidos graxos poli-insaturados da família ômega 3 } \\ \text { AGPIn-6 } & \text { Ácidos graxos poli-insaturados da família ômega 6 } \\ \text { AGs } & \text { Ácidos graxos } \\ \text { ATCC } & \text { American Type Cell Collection } \\ \text { BRCA1 } & \text { Breast cancer 1, early onset } \\ \text { cDNA } & \text { DNA complementar } \\ \text { CEP } & \text { Comitê de Ética em Pesquisa } \\ \text { CBAs } & \text { Compostos bioativos de alimentos } \\ \text { CO } & \\ \text { CpG } & \text { Dióxido de carbono } \\ \text { DCIS } & \text { Citosina-fosfodiéster-guanina } \\ \text { DCNTs } & \text { Ductal carcinoma in situ } \\ \text { DEPEC } & \text { Doenças crônicas não-transmissíveis } \\ \text { DHA } & \text { Dietilpirocarbonato } \\ \text { DMSO } & \text { Ácido docosahexaenoico } \\ \text { DMEM } & \text { Dimetilsulfóxido } \\ \text { DNMTs } & \text { Meio de Eagle modificado por Dulbecco } \\ \text { dNTP } & \text { DNA metiltransferases } \\ \text { ECL } & \text { Desoxiribonucleotídeos } \\ \text { EPA } & \text { Enhanced chemiluminescence } \\ \text { ER } & \text { Ácido eicosapentaenoico } \\ & \text { Receptor de estrógeno } \\ & \end{array}$


FMUSP Faculdade de Medicina da Universidade de São Paulo

9 Força da gravidade (aceleração centrípeta)

GAPDH Glyceraldehyde 3-phosphate dehydrogenase

GSTP1 Glutathione S-transferase pi 1

HER-2 Receptor de fator de crescimento epidermal 2

$\mathrm{HCl} \quad$ Ácido clorídrico

HDACs Histone deacetylases

HEPES 4-(2-hydroxyethyl)-1-piperazineethanesulfonic acid

INCA Instituto Nacional do Câncer

MCF-7 Linhagem celular de adenocarcinoma de mama humano

MDA-MB-231 Linhagem celular epitelial mamária humana

MS-PCR Methylation-specific Polymerase chain reaction

pb Pares de bases

PBS Tampão fosfato salino

PI lodeto de propídio

PR Receptor de progesterona

RAR $\beta$ Retinoic acid receptor, beta

RASSF1A RAS-association domain 1 isoform A

RNA Ácido ribonucleico

RNAm Ácido ribonucleico mensageiro

RPMI Meio de cultura

RT

Enzima Transcriptase Reversa

RT-qPCR Reação da transcriptase reversa, seguida de reação em cadeia da polimerase quantitativa

SAH S-adenosylhomocysteine

SAM S-adenosylmethionine

SFB Soro fetal bovino

SKBR-3 Células luminais de adenocarcinoma de mama humano

SREBP Sterol regulatory element binding transcription factor 2

THR $\beta \quad$ Thyroid hormone receptor, beta 


\section{Lista de Figuras}

Figura 1: (A) Esquema das principais modificações epigenéticas. ..............7

Figura 2: Elongação e dessaturação de AGs n-6 e n3............................17

Figura 3: Representações de três ensaios independentes da análise de acetilação no resíduo de lisina 9 histona 3 (H3K9ac) e no resíduo 16 histona 4 (H4K16ac) nas linhagens MCF-7, MDAMB-231 e SKBR-3.

Figura 4: Representações de três ensaios independentes da análise de trimetilação no resíduo de lisina 9 histona 3 (H3K9me3) e no resíduo 27 histona 3 (H3K27me3) nas linhagens MCF-7, MDA-MB-231 e SKBR-3.

Figura 5: Box plot representativo de três ensaios independentes da expressão relativa do gene RASSF1A por RT-qPCR.

Figura 6: Representação de três ensaios independentes da análise do padrão de metilação da região promotora do gene RASSF1A das linhagens MDA-MB-231, SKBR3 e MCF-7

Figura 7: Box plots representativos das expressões relativas dos genes DNMT1, DNMT3A e DNMT3B por RT-qPCR das linhagens MDA-MB-231, MCF-7 e SKBR3.

Figura 8: Histogramas (FL2A) representativos da distribuição no ciclo celular das linhagens MDA-MB-231, SKBR-3 e MCF-7. 


\section{RESUMO}

Castro RCB. Efeito do ácido docosahexaenoico (DHA) sobre eventos epigenéticos em diferentes linhagens de câncer de mama [Dissertação]. São Paulo: Faculdade de Medicina, Universidade de São Paulo, 2013. 66p.

Alterações epigenéticas, como metilação do DNA e modificações pós traducionais em histonas, tem importante papel na carcinogênese mamária. A modulação de eventos epigenéticos constitui relevante alvo terapêutico, devido ao seu caráter reversível. Experimentalmente, o ácido docosahexaenoico (DHA), um membro da família dos ácidos graxos ômega-3, é capaz de diminuir proliferação, induzir morte celular e diminuir o potencial invasivo de células tumorais de mama. No entanto, os mecanismos antitumorais do DHA e sua capacidade de modular eventos epigenéticos ainda não estão totalmente elucidados. Nosso objetivo foi verificar, in vitro, a ação do DHA em eventos epigenéticos em diferentes linhagens de carcinoma mamário humano. Três linhagens celulares de câncer de mama (MDAMB-231, SKBR-3 e MCF-7) foram tratadas durante 72 horas com $100 \mu \mathrm{M}$ de DHA ou etanol (controle). As modificações pós traducionais em histonas, acetilação no resíduo de lisina 9 da histona 3 (H3K9ac) e no resíduo 16 da histona 4 (H4K16ac), bem como trimetilação no resíduo de lisina 9 da histona 3 (H3K9me3) e no resíduo de lisina 27 da histona 3 (H3K27me3) foram avaliadas pela técnica de western blot. A análise da expressão do genes RASSF1A, DNMT1, DNMT3A e DNMT3B foi feita pela técnica da reação em cadeia da polimerase quantitativa via transcriptase reversa (RT-qPCR). A avaliação do padrão de metilação de região promotora do gene RASSF1A foi realizada pela técnica de reação em cadeia da polimerase metilação específica (MS-PCR). Foram também analisadas as fases do ciclo celular por citometria de fluxo. Comparado ao controle, o DHA induziu a acetilação no resíduo 16 da histona 4 (H4K16ac) nas linhagens MCF7 ( $p=0,04)$ e MDA-MB-231 $(p=0,03)$. Observamos que a H3K9me3 foi parcialmente inibida nas linhagens MDA-MB-231 e SKBR-3, após o tratamento com DHA, mas sem alcançar valor estatisticamente significante. Encontramos também diminuição dos níveis de H3K27me3 após o tratamento com DHA nas três linhagens estudadas, porém não foi estatisticamente significativo. O DHA aumentou a expressão do gene RASSF1A na linhagem MCF-7 (1,98 vezes, $p=0,03)$, mas não nas linhagens MDA-MB-231 e SKBR-3. Não houve mudanças estatisticamente significativas na expressão dos genes DNMT1, DNMT3A e DNMT3B. As análises qualitativas da metilação demonstraram que a região promotora analisada do gene RASSF1A apresentou-se hipermetilada nas três linhagens celulares. Após o tratamento com DHA, houve tendência de desmetilação na região promotora do RASSF1A na linhagem MCF-7 e SKBR3, mas não na linhagem MDA-MB-231. Não houve diferença significativa na porcentagem de morte e distribuição das células MDA-MB-231, SKBR-3 e MCF-7 nas diferentes fases do ciclo celular após tratamento com DHA. Em conclusão, o DHA pode atuar em mecanismos epigenéticos e, ainda, reativar o gene supressor de tumor, como RASSF1A, anteriormente silenciado por hipermetilação, em células MCF-7. Espera-se que esses resultados contribuam para melhor compreensão do potencial papel anticâncer do DHA no câncer de mama.

Descritores: 1.Ácidos graxos ômega-3 2.Ácidos docosa-hexaenoicos 3.Neoplasias da mama 4.Metilação de DNA 5.Repressão epigenética 6. Histonas 7.Acetilação/efeitos de drogas 8.Regulação neoplásica da expressão gênica 9.Nutrigenômica 10.Anticarcinógenos/farmacologia 11.Linhagem celular tumoral 12.Nutrição 


\section{SUMMARY}

Castro RCB. Effect of docosahexaenoic acid (DHA) on epigenetic events in diferente breast cancer cell lines [Dissertation]. São Paulo: "Faculdade de Medicina, Universidade de São Paulo", 2013. 66p.

Epigenetic changes, such as DNA methylation and post-translational histone modifications, play an important role in mammary tumorigenesis. Epigenetic events are important as therapeutic targets, because of its reversible nature. Experimentally, docosahexaenoic acid (DHA), a member of the omega-3 fatty acids family, can reduce proliferation, induce apoptosis and decrease the invasive potential of breast tumor cells. However, the antitumor mechanism of DHA and its ability to modulate epigenetic events are not completely understood. Our objective was to verify, in vitro, the action of DHA in epigenetic events related to transcriptional reactivation of tumor suppressor gene, such as RASSF1A, in different human breast cancer cell lines. Three breast cancer cell lines (MCF-7, MDA-MB231, SKBR-3) were treated with DHA $(100 \mu \mathrm{M})$ or vehicle (ethanol) for 72 hours. Western blot was used to analyze histone modification, as histone H3 lysine 9 (H3K9ac) and histone $\mathrm{H} 4$ lysine 16 (H4K16ac) acetylation, H3K9 trimethylation (H3K9me3) and H3K27 trimethylation (H3K27me3). Real time quantitative PCR (RT-qPCR) was performed for gene expression quantification of RASSF1A, DNMT1, $D N M T 3 A$ and DNMT3B. DNA methylation of the promoter region of RASSF1A was evaluated by methylation specific PCR (MS-PCR). Moreover, we evaluated the phases of the cell cycle by flow cytometry. Compared to control cells, DHA induced H4K16ac in MCF-7 $(p=0.04)$ and MDA-MB-231 $(p=0.03)$. We observed that H3K9me3 was partially inhibited in MDA-MB-231 and SKBR-3 cells, after treatment with DHA, but did not reach a statistically significant value. We also found decreased levels of H3K27me3 after treatment with DHA in the three cell lines studied, but not statistically significant. DHA increased RASSF1A expression on MCF-7 (1.98 fold; $p=0.03$ ), but not in MDA-MB-231 and in SKBR-3 cells. There were no statistically significant changes in expression of genes DNMT1, DNMT3A and $D N M T 3 B$. These three breast cancer cells lines show methylation in specific region of RASSF1A promoter. DHA treatment increased RASSF1A promoter region hypomethylation in MCF-7 and SKBR-3. No significant difference was observed in the percentage of cell death nor cell distribution of MDA-MB-231, SKBR-3 and MCF7 at different stages of the cell cycle after treatment with DHA. In conclusion, we suggest that DHA may act beneficially in epigenetic mechanisms and reactivation of tumor suppressor gene, RASSF1A as previously silenced by hypermethylation. It is hoped that these results can contribute to better understanding of the anticancer role of DHA in breast cancer.

Descriptors: 1.Fatty acids, omega-3 2.Docosahexaenoic acids 3.Breast neoplasms 4.DNA methylation 5.Epigenetic repression 6.Histones 7.Acetylation/drug effects 8.Gene expression regulation, neoplastic 9.Nutrigenomics 10.Anticarginogenic agents/pharmacology 1..Cell line, tumor 12.Nutrition 
O câncer de mama permanece atualmente como o segundo tipo de câncer mais frequente no mundo e o primeiro entre as mulheres $[1,2]$. A carcinogênese mamária envolve estágios contínuos, em que células luminais epiteliais adquirem características que permitem rápida proliferação, progressão para carcinoma in situ, invasão do tecido adjacente e metástase. Estas alterações ocorrem concomitantemente ao ganho de atividade oncogênica e perda de funções de genes supressores tumorais [3, 4]. Esse processo ocorre devido às complexas alterações genéticas e epigenéticas que afetam os padrões de expressão gênica [5-7]. Diferente das alterações genéticas, que são irreversíveis, as mudanças epigenéticas são reversíveis, criando a possibilidade de desenvolvimento de novas terapias baseadas na restauração funcional de genes associados ao câncer. Com isso, os a compreensão de mecanismos epigenéticos está se tornando cada vez mais relevante [7].

Os eventos epigenéticos podem ser definidos como alterações estáveis e potencialmente herdáveis na expressão gênica, que não alteram a sequência de nucleotídeos do DNA [8]. Esses eventos envolvem mecanismos de ativação ou silenciamento de genes por meio de modificações na conformação da cromatina, dos quais os mais amplamente estudados são as modificações pós traducionais em histonas e a metilação do DNA [9].

As histonas são proteínas com ação essencial na manutenção do equilíbrio dinâmico da cromatina e na regulação da expressão gênica [10]. A acetilação em histonas específicas, por exemplo, tem sido associada com configuração da cromatina menos compactada (eucromatina), permitindo a transcrição de genes. Por outro lado, a desacetilação de histonas está relacionada com configuração mais compactada da cromatina (heterocromatina), levando ao silenciamento de genes [11, 12].

A metilação do DNA consiste na adição covalente de um radical metil $\left(\mathrm{CH}_{3}\right)$ a uma base citosina no DNA, convertendo-a em 5-metilcitosina. Essa reação ocorre quase que exclusivamente nas citosinas ligadas à guanina 
por uma ligação fosfodiéster, denominadas dinucleotídeos ou ilhas CpG, e que se localizam principalmente na região promotora dos genes [13].

Existem dois padrões distintos de metilação aberrante do DNA no câncer: a hipermetilação do DNA em regiões promotoras e hipometilação global do DNA. A hipermetilação do DNA na região promotora é a mudança epigenética mais estudada e é encontrada em vários tipos de câncer. Ela pode resultar em silenciamento de genes supressores tumorais e genes de reparo de danos ao DNA. Fisiologicamente, os genes supressores tumorais contêm ilhas CpG não metiladas na sua região promotora, mas, de forma diferente, estas encontram-se metiladas em diversos tipos de cânceres. A hipermetilação do DNA pode ser considerada um importante marcador de perda de função do gene e, potencialmente preditor de prognóstico [14]. Dentre os diversos genes hipermetilados no câncer, o RASSF1A (Ras Association Domain Family Protein 1) vem ganhando destaque. Sua hipermetilação é observada em 60-77\% em câncer de mama, que resulta no seu silenciamento em linhagens celulares e em tumores primários [15-17], como fator independente de pior prognóstico [18-20].

A evolução dos estudos em biologia molecular do câncer de mama vem ampliando a compreensão da influência da dieta no processo da carcinogênese mamária. Observações epidemiológicas sugerem que o aumento da ingestão de óleo de peixe, principal fonte de ácidos graxos ômega 3 (AG n-3), pode estar associada à redução da incidência do câncer de mama [21]. Estudos experimentais têm consistentemente observado que AG n-3 podem suprimir a formação e o desenvolvimento do câncer de mama in vitro e in vivo [22-25]. Uma série de mecanismos têm sido propostos para as ações anticarcinogênicas dos $A G n-3$, incluindo a supressão de transformação neoplásica, inibição da proliferação celular, aumento da apoptose e antiangiogênese [26-31].

Os efeitos anti-tumorais dos AG n-3, particularmente ácido eicosapentaenoico (EPA) e ácido docosahexaenoico (DHA), parecem ser semelhantes na maior parte dos estudos, no entanto recentes pesquisas 
demonstram diferentes mecanismos de ação quando eles são estudados isoladamente. De maneira geral, os estudos experimentais atribuem maior potencial antitumoral ao DHA [32-34]. Em pesquisa realizada em nosso laboratório (Laboratório de Nutrição e Cirurgia Metabólica do Aparelho Digestivo - LIM 35) observou-se que, ao se comparar EPA com DHA, o tratamento com $100 \mu \mathrm{M}$ de DHA aumentou sua concentração na membrana plasmática da linhagem celular de mama com superexpressão de HER-2 (linhagem HB4aC5.2). O DHA induziu apoptose, alterou a distribuição das células nas fases do ciclo celular e desestruturou os lipid rafts [35]. Estudo em andamento do nosso laboratório, em condições semelhantes, verificou que o DHA pode alterar a expressão gênica de maneiras distintas, dependendo das características celulares. O DHA pode alterar a expressão gênica de vias do metabolismo lipídico de células que hiperexpressam HER-2 e aumenta a expressão de genes supressores tumorais como, por exemplo, SERPINB5 (serpin peptidase inhibitor, clade B, member 5), CLDN1 (claudin 1) e CDKN1A (cyclin-dependent kinase inhibitor 1A). Outros estudos vêm demonstrando a ação do DHA na reativação de genes supressores tumorais como $B R C A 1$ (breast cancer 1) e BRCA2 (breast cancer 2) [36], e o PTEN (phosphatase and tensin homolog) [37]. Estes genes supressores de tumor são susceptiveis ao silenciamente epigenético. É possível que o DHA possa influenciar vias que controlam eventos epigenéticos de reativação gênica.

Portanto, a avaliação do envolvimento do DHA em eventos epigenéticos poderia contribuir com informações relevantes na compreensão de sua ação no combate à célula cancerígena e posterior potencial uso clínico. Assim, nossa hipótese de trabalho considerou que o tratamento com DHA em diferentes linhagens celulares de câncer de mama fosse capaz de modular mecanismos epigenéticos que podem, inclusive, estar relacionados à reativação gênica de supressor de tumor. Para isso, foram avaliados em três diferentes linhagens celulares de câncer de mama tratadas com DHA, as modificações pós traducionais em histonas, a expressão do gene RASSF1A, bem como o padrão de metilação de sua região promotora. 


\subsection{Câncer, epigenética e nutrição}

O câncer é um termo geral que representa mais de 100 doenças, e cada tipo apresenta etiologia própria. Segundo o Instituto Nacional do Câncer (INCA), o número estimado para 2012/2013 é de 518.510 casos novos de câncer no Brasil, incluindo os casos de pele não melanoma, que é o tipo mais incidente para ambos os sexos (134 mil casos novos), seguido por próstata (60 mil), mama feminina (53 mil), cólon e reto (30 mil), pulmão (27 mil), estômago (20 mil) e colo do útero (18 mil) [1].

A perda do controle da proliferação celular e a aquisição de características associadas com a progressão tumoral são consequências de alterações que ocorrem no conteúdo genético e epigenético das células tumorais. A célula alterada, por adquirir uma maior capacidade de proliferação em relação às células vizinhas, pode transmitir essa alteração para todas as células que, a partir dela, possam se originar [7, 38]. As alterações genéticas que levam ao câncer incluem amplificação gênica, deleções, mutações pontuais, perda de heterozigose e rearranjos cromossômicos. Diferente das alterações genéticas, que são irreversíveis, as mudanças epigenéticas, que incluem metilação do DNA, modificação pós-traducionais de histonas, microRNAs, e componentes de compactação da cromatina, são reversíveis. Com isso estabelece-se a possibilidade de desenvolvimento de novas terapias baseadas na restauração epigenética funcional de genes associados ao câncer $[39,40]$. Com isso, o estudo de mecanismos epigenéticos está se tornando cada vez mais relevante, por seu papel importante na carcinogênese [41] e por estar presentes em todos os estágios da doença [7, 38].

A definição de epigenética foi utilizada pela primeira vez em 1957 por Conrad Waddington para descrever a maneira como o mesmo genótipo pode dar origem a diferentes fenótipos durante o desenvolvimento de um organismo. Quase quarenta décadas depois, em 1996, Riggs e colaboradores definiram epigenética como "o estudo das mudanças hereditárias na expressão de genes durante a mitose e /ou meiose que não são causadas 
por alterações na sequência do DNA". Mais tarde, Bird em 2007 complementou esses conceitos e propôs uma definição unificadora dos eventos epigenéticos: adaptação estrutural de regiões cromossômicas, a fim de registrar, sinalizar ou perpetuar a atividade da expressão gênica [8]. Os mecanismos epigenéticos envolvem alteração química no DNA e na cromatina, das quais os mais amplamente estudados são a metilação do DNA e as modificações pós traducionais em histonas (Figura 01).

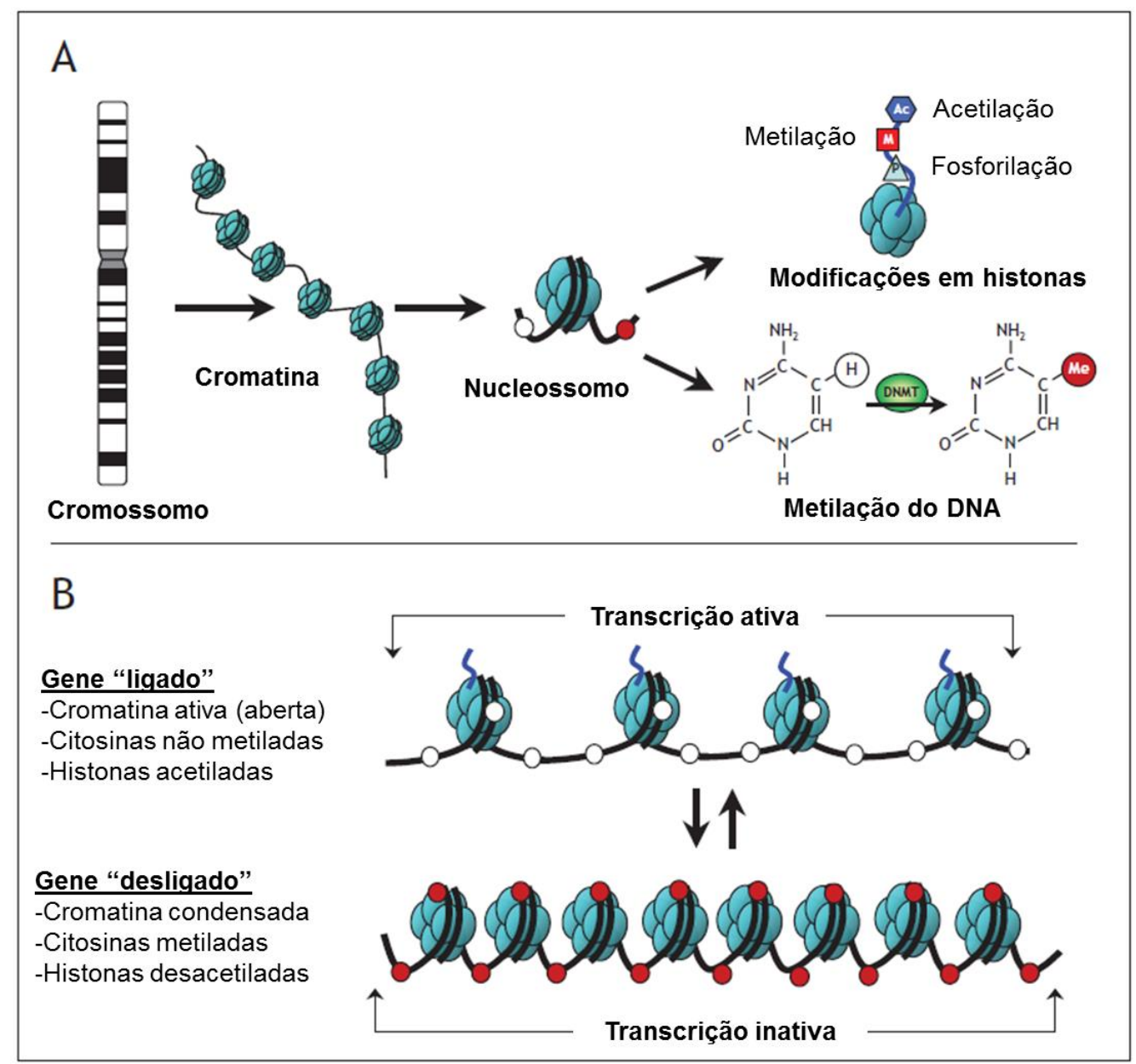

Figura 01: (A) Esquema das principais modificações epigenéticas. As fitas de DNA encontram-se enroladas em octâmeros de histonas, formando nucleossomos. Estes nucleossomos são organizados em cromatina. Modificações reversíveis em sítios especificos de histonas ocorrem através de reações como metilação, acetilação e fosforilação. A metilação do DNA ocorre na posição 5 de resíduos de citosina em reação catalisada por DNA metiltransferases (DNMTs). Juntas, essas modificações regulam a organização da cromatina e expressão de genes. (B) Esquema das alterações reversíveis da organização da cromatina que influencia na expressão de genes: os genes são expressos quando a cromatina está relaxada (ativa), e eles são inativados quando a cromatina está condensada (inativa). Círculos brancos = citosinas não metiladas, círculos vermelhos $=$ citosinas metiladas. FONTE: Adaptado de Rodenhiser \& Mann [42]. 


\subsubsection{Modificações pós traducionais em histonas}

A compactação do DNA no núcleo celular é importante para diversos processos fisiológicos. O primeiro nível de compactação é o enrolamento do DNA ao redor das histonas formando nucleossomos que, por sua vez, formam estrutura altamente complexa e dinâmica denominada cromatina. As histonas são proteínas importantes na manutenção do equilíbrio dinâmico da cromatina e, consequentemente, regulam a expressão gênica [10].

Os nucleossomos são considerados a estrutura repetitiva básica da cromatina e contêm cerca de 146 pares de base (p.b) de DNA enrolados ao redor de um octâmero nuclear de histonas. Esse octâmero é constituído por um tetrâmero de histonas H3-H4 e dois dímeros H2A e H2B. As histonas são proteínas básicas com um domínio globular e extremidades amino-terminais ricas em lisina, contendo a maior parte dos sítios que sofrem modificação póstradução [43, 44]. Os resíduos amino-terminais são suscetíveis à modificações, que incluem acetilação, metilação, fosforilação, entre outras [9, 45]. O conjunto destas modificações representa um complexo de informações epigenéticas conhecido como o código das histonas [39, 46]. Existem várias combinações possíveis entre essas modificações, formando uma rede de comunicação relacionada a diversos processos biológicos [47], incluindo, transcrição gênica, duplicação do DNA, progressão do ciclo celular e diferenciação [48]. Embora o código das histonas não esteja totalmente compreendido, marcas específicas, como acetilação em lisina (exemplos, H3K9ac e H4K16ac) e trimetilação em lisina (H3K4me3), estão associados com os promotores de genes transcricionalmente ativos, enquanto que outras modificações como a metilação em lisina (exemplos, H3K9me3 e H3K27me3) estão associadas com cromatina compactada [49].

$\mathrm{Na}$ variedade de modificações pós traducionais em histonas, a acetilação em histonas tem sido a mais estudada [50]. A acetilação em histonas específicas tem sido associada com a configuração da cromatina relaxada, permitindo a transcrição de genes [51]. Por outro lado, a desacetilação em histonas está relacionada com a configuração compactada, 
levando ao silenciamento de genes [11]. Em condições fisiológicas, a acetilação da cromatina é regulada pela ação da acetiltransferases de histonas (HATs), que utiliza grupo acetil a partir de acetil-CoA, e desacetilases de histonas (HDACs) [11].

A acetilação neutraliza a carga positiva das histonas, diminuindo a afinidade das histonas pelo DNA, que possui carga negativa. Esse evento permite o desprendimento da terminação da histona do nucleossomo, afrouxando a estrutura da cromatina, que se encontra normalmente superespiralada, aumentando o acesso de proteínas ligantes do DNA e reguladoras da transcrição, às regiões promotoras dos genes [12].

Durante o desenvolvimento do câncer, podem ocorrer atividades aberrantes das modificações em histonas [52]. O balanço entre a ação da HAT e HDAC é essencial para a manutenção da função celular normal, e a mudança neste balanço em ambos sentidos pode ter consequências no fenótipo celular, como na carcinogênese [11, 53], em que as HDACs estão superexpressas. Os inibidores HDAC (HDACi) bloqueiam a proliferação celular, e induzem à apoptose e diversos deles estão sendo investigados em ensaios clínicos como agentes anticâncer, em doses bem toleradas [54]. Outra característica importante de HDACis é sua seletividade em alterar a expressão gênica em células transformadas. Além disso, HDACi pode melhorar a sensibilidade à quimioterapia e inibir a angiogênese $[11,55]$.

\subsubsection{Metilação do DNA}

A metilação do DNA consiste na adição covalente de um radical metil $\left(\mathrm{CH}_{3}\right)$ a uma base citosina no DNA, convertendo-a em 5-metilcitosina. Esta reação é catalisada por enzimas denominadas DNA metiltransferases, como DNMT1, DNMT3A e DNMT3B [9]. A DNMT1 é conhecida como DNA metiltransferase de manutenção, envolvida na conservação dos padrões de metilação do DNA durante a divisão celular. Já a DNMT3A e DNMT3B são conhecidas como metiltransferases de novo e estão altamente expressas em 
células embrionárias, pois é nesta fase que os eventos de metilação de novo mais ocorrem. A metilação do DNA ocorre em citosinas unidas à guanina por uma ligação fosfodiéster, denominadas dinucleotídeos ou ilha CpG, que se localizam principalmente na região promotora dos genes [13].

A hipermetilação do DNA é a mudança epigenética mais estudada e é encontrada em vários tipos de câncer [56,57]. Ela resulta em silenciamento de genes supressores tumorais e genes de reparo de danos ao DNA. Fisiologicamente, os genes supressores tumorais contêm ilhas $\mathrm{CpG}$ não metiladas na sua região promotora, mas se encontram metiladas em diversos tipos de cânceres [58]. Evidências sugerem que DNMT1 e DNMT3B podem atuar em conjunto para estabelecer e manter um fenótipo hipermetilado em células tumorais. Assim, essas enzimas poderiam, potencialmente, contribuir para o aumento do estado de hipermetilação (através da metilação de novo - DNMT3B), e também garantir a herança de silenciamento de genes (através da metilação de manutenção - DNMT1) [59]. A lista de genes associados com hipermetilação de ilhas CpG na região promotora tem sido ampliada nos últimos anos, bem como tem sido avaliado ativamente seu papel potencial como alvo terapêutico [39].

A hipometilação global também é encontrada em diversos tipos de cânceres. Embora o mecanismo preciso por que a perda global de metilação do DNA contribui para o processo neoplásico ainda não esteja totalmente entendido, acredita-se que ele induza à ativação de oncogenes e a instabilidade cromossômica [60, 61].

A capacidade reversível dos mecanismos epigenéticos tem sido alvo promissor para 0 tratamento do câncer. A terapia epigenética tem por objetivo restabelecer os padrões normais de metilação do DNA e impedir que as ilhas $\mathrm{CpG}$ adquiram maior nível de metilação. $O$ tratamento de células neoplásicas com agentes desmetilantes pode reativar um grupo de genes que muitas vezes são cruciais para o controle da proliferação celular, diferenciação, apoptose e outros mecanismos homeostáticos [39]. 


\subsubsection{O papel dos nutrientes em modificações pós traducionais em histonas e na metilação do DNA}

O risco de câncer é influenciado por fatores genéticos e ambientais, incluindo os hábitos alimentares [62]. Desde 1981, os pesquisadores Doll e Peto estimaram que cerca de $35 \%$ de todas as mortes causadas pelo câncer poderiam ser atribuídas ou até mesmo prevenidas pela dieta. Esses pesquisadores consideraram a dieta como um contribuinte tão importante quanto o uso de tabaco para o desenvolvimento do câncer [63].

Após quase 30 anos e depois de uma complexa revisão de todas as evidências, o World Cancer Research Fundation e a American Institute for Cancer Research (WCR/AICR) publicaram em 2007 um documento "Alimentos, Nutrição, Atividade Física e Prevenção de Câncer: uma perspectiva global", concluindo que o câncer é principalmente causado por fatores ambientais, dos quais os mais importantes são: o tabaco; a dieta e fatores relacionados à dieta, incluindo aumento da massa corpórea; sedentarismo; exposição à carcinógenos no ambiente de trabalho ou outros locais [64].

Estudos epidemiológicos sugerem que a ingestão de carne vermelha, gordura animal e alguns óleos vegetais, podem aumentar a incidência de câncer. Por outro lado, a ingestão de frutas, hortaliças, peixes e seus óleos foram associados com a redução do risco de doenças malignas [65].

Pesquisas que buscam estudar os mecanismos da interação nutriente-gene são necessárias para entender como a dieta modula o risco de desenvolver doenças crônicas, como o câncer. Em consequência disso, nos últimos anos, verificou-se que alguns compostos bioativos de alimentos (CBAs) são capazes de atuar em eventos epigenéticos [66, 67].

Inicialmente, os estudos levantaram a possibilidade de que fatores ambientais, incluindo a dieta, são reguladores chave dos eventos epigenéticos, participando da metilação do DNA e de modificações pós traducionais em histonas $[68,69]$. 
A metilação do DNA é catalisada por uma família de DNA metiltransferases (DNMTs) que utiliza a S-adenosilmetionina (SAM) como doadora do radical metil $\left(\mathrm{CH}_{3}\right)$. A SAM é uma molécula gerada no ciclo da metionina [70] e a sua disponibilidade é diretamente influenciada pela dieta. O folato, a vitamina B12 e B6, a colina e betaína, estão metabolicamente relacionados na formação da metionina e na sua conversão em SAM. Assim, mecanimos epigenéticos podem ser diretamente influenciados por esses nutrientes [71].

Alguns CBAs foram identificados como inibidores da DNA metiltransferase e podem apresentar efeito potencial na prevenção do câncer. A epigalocatequina-3-galato (EGCG), o principal polifenol do chá verde, inibe a enzima DNA metiltransferase (DNMT) e, assim, pode reativar genes silenciados, como o CDKN2A (cyclin-dependent kinase inhibitor 2A) e MLH1 (mutL homolog 1, colon cancer, nonpolyposis type 2) em células do tumorais [72, 73].

As modificações pós traducionais em histonas também podem ser alteradas por CBAs, através de atuação em HDAC. Alguns compostos com ação quimiopreventiva, como o butirato, dialil dissulfeto e sulforafano, possuem atividade inibitória da HDAC [60] e alteram a expressão de genes. Dashwood et al [74] sugeriu que esses CBAs podem levar à mudanças conformacionais no sítio ativo da HDAC, levando a sua desativação. A contínua exposição a estes componentes bioativos é necessária para manter o controle dos mecanismos epigenéticos [51]. Estes estudos destacam a ideia de que a dieta possui diferentes substâncias que, na dependência do tempo de exposição e concentrações, são capazes de modular os eventos epigenéticos. Estratégias utilizando componentes dietéticos envolvidos nesse processo poderão, no futuro, ser úteis na prevenção ou inibição da carcinogênese [66]. 


\subsection{Alterações epigenéticas no câncer de mama}

O câncer de mama é o tipo mais frequente no mundo entre as mulheres. A cada ano, cerca de 1,38 milhões de mulheres são diagnosticadas e 458503 morrem da doença [75]. Segundo dados do INCA, o número de casos de câncer de mama estimados para o ano de 2012 no Brasil é de 52.680, com risco estimado de 52 casos a cada 100 mil mulheres [1]. A incidência de câncer de mama em países emergentes, como o Brasil, está aumentando e tem sido atribuído ao aumento da urbanização e ao padrão alimentar inadequado [2].

O modelo mais estudado da carcinogênese mamária humana envolve um processo que progride em estágios contínuos, em que se inicia com atipia de células luminais epiteliais, avança para hiperplasia ductal atípica, evolui para carcinoma ductal in situ (CDIS) e culmina na fase de carcinoma ductal invasivo [4]. O prognóstico dos cânceres de mama é determinado por variáveis clínico-patológicas tradicionais, que incluem tamanho, grau e expressão de receptores de superfície celular [76]. Recentemente as alterações moleculares vêm ganhando destaque na classificação nos tumores de mama e os estudos que analisaram perfis de expressão gênica revelaram que os tumores de mama podem ser estratificados em subtipos moleculares [77].

Nos últimos anos, descreveram-se alterações nos mecanismos epigenéticos associadas com as diferentes fases da progressão do câncer de mama. Acredita-se que mudanças epigenéticas sejam importantes para a iniciação da tumorigênese e a manutenção do estado alterado das células tumorais [78].

Evidências sugerem que o genoma das células tumorais de mama apresenta redução de até $50 \%$ do conteúdo de 5-metilcitosina, o que caracteriza a hipometilação global do DNA [79]. Ao lado da hipometilação global do DNA ocorre, concomitantemente, a hipermetilação em região promotora de genes supressores de tumor e genes de reparo de danos ao DNA [80]. 
A hipermetilação do DNA pode ser considerada um importante marcador de perda de função do gene e, potencialmente preditor de prognóstico [14]. No câncer de mama, entre os genes comumente metilados, em região promotora, incluem-se o receptor de estrógeno $(E R)$, progesterona (PR), E-caderina, RASSF1A, SCGB3A1 (HIN1), TWIST1 (twist basic helix-loop-helix transcription factor 1), a ciclina D2, RARß (retinoic acid receptor, beta), THR $\beta$ (thyroid hormone receptor, beta), BRCA1 e o GSTP1 (glutathione S-transferase pi 1) [81-83]. Dentre esses genes, o RASSF1A vem ganhando destaque [81-83], pois a hipermetilação em sua região promotora é observada em $60-77 \%$ em câncer de mama e o seu silenciamento ocorre em linhagens celulares e em tumores primários [15-17]. O silenciamento epigenético do RASSF1A, em câncer de mama, vem sendo considerado parâmetro independente de pior prognóstico [18-20].

O gene supressor tumoral RASSF1A codifica uma proteína responsável pela regulação da transição de fase do ciclo celular e apoptose [84]. Experimentalmente, a superexpressão do RASSF1A promove apoptose e parada de ciclo celular. Estudos, in vitro e in vivo, demonstraram que baixos níveis de expressão do RASSF1A estão relacionados com perda de controle do ciclo celular, aumento da motilidade celular, instabilidade genômica e resistência à apoptose [85-88].

A superexpressão de DNA metiltransferases, principalmente DNMT1 e DNMT3B, ocorre em diversos tipos de câncer, incluindo o câncer de mama. A indução da superexpressão de DNMT1 in vitro aumenta gradualmente a hipermetilação em ilhas $\mathrm{CpG}$ e induz à transformação neoplásica maligna [89].

Distúrbios nas modificações pós traducionais em histonas também têm sido descritos na carcinogênese mamária e estão associados com desregulação e silenciamento epigenético de diversos genes que desempenham papéis importantes no ciclo celular e apoptose [16]. Dentre as diversas reações que modificam as histonas, a acetilação é a melhor caracterizada. A acetilação, no resíduo de lisina em histonas $\mathrm{H} 3$ ou $\mathrm{H} 4$ (H3K9ac e H4K16ac), leva ao estado de cromatina não compactada em 
regiões reguladoras de genes, permitindo a ligação dos fatores de transcrição. A perda global de acetilação em H4K16 foi observada juntamente com a hipometilação global do DNA em diversos cânceres primários tendo sido, em conjunto, consideradas alterações epigenéticas iniciais durante a tumorigênese [90]. O aumento de H4K16ac foi relacionado com aumento de sensibilidade de células tumorais à quimioterapia e sua desacetilação se correlaciona com a progressão do tumor $[49,90]$.

\section{3 Ácidos graxos ômega-3 e sua relação com o câncer de mama}

Os ácidos graxos (AG) são ácidos carboxílicos representados pela fórmula $\mathrm{R}-\mathrm{CO}_{2} \mathrm{H}$, em que o radical $\mathrm{R}$ é geralmente uma cadeia carbônica, não ramificada, com número par de átomos de carbono, unidos por ligações simples ou duplas. Os ácidos graxos podem ser classificados, de acordo com o grau de saturação, número total de carbonos e pela essencialidade [91, 92].

O grau de saturação é caracterizado pelo número de duplas ligações: saturados (sem duplas ligações), monoinsaturados (uma dupla ligação e poli-insaturados (mais de uma dupla ligação). Os ácidos graxos têm cadeias com distintos números de átomos de carbono e podem ser: ácidos graxos de cadeia curta (AGCC - 2 a 4 carbonos), ácidos graxos de cadeia média (AGCM - 6 a 12 carbonos) e ácidos graxos de cadeia longa ( $A G C L-14$ a 22 carbonos) [91, 92].

A essencialidade dos ácidos graxos é determinada pela capacidade de serem produzidos bioquimicamente ou não pelo organismo. Os mamíferos podem sintetizar ácidos graxos a partir de acetil-CoA, por meio da síntese de novo de AGs. O produto final da enzima ácido graxo sintetase é o ácido palmítico (16:0), o qual pode ser elongado a ácido esteárico (18:0) e a outros ácidos graxos saturados de cadeia longa. A enzima $\Delta^{9}$ 
dessaturase, presente em plantas e animais, introduz uma dupla ligação entre o carbono 9 e 10, convertendo o ácido esteárico em oleico (18:1, n-9 ou $\omega-9)$, com uma única insaturação na nona posição a partir do hidrocarboneto terminal. Estes ácidos graxos além de serem sintetizados pelos mamíferos, também são obtidos pela dieta.

No entanto, há um grupo de ácidos graxos, denominados essenciais, que só podem ser obtidos pela dieta [93], devido à ausência, em mamíferos, de enzimas para a sua biossíntese. As principais insaturações destes AGs essenciais estão na terceira ( $n-3$ ou $\omega-3$ ) ou sexta posição ( $n-6$ ou $\omega-6)$, a partir da extremidade metil (distal). Por que esses AGs não podem ser produzidos endogenamente pelo homem, eles devem ser fornecidos exclusivamente pela dieta, e por isso chamados de essenciais [94].

Os ácidos linoleico (C18:2 n-6, [LA]) (essencial) e $p$-linolênico (C18:3 $\mathrm{n}-6,[\mathrm{GLA}]$ ) são precursores do ácido araquidônico (C20:4 n-6, [AA]) e pertencem à família dos $A G n-6$. $O$ ácido graxo essencial que pertence à família n-3 é o ácido a-linolênico (C18:3 n-3 [ALA]), que é precursor de eicosapentaenoico (C20:5 n-3, [EPA]) e o docosahexaenoico (C22:6 n-3, [DHA]). As células animais podem apenas converter o ALA em outros ácidos graxos da mesma família $n-3$, como o EPA e DHA. Por sua vez, o $y^{-}$ linolênico dá origem ao ácido araquidônico da mesma família n-6. Com isso, AGs de famílias diferentes não se interconvertem (Figura 02) [91, 94, 95].

Uma das principais características do AG n-3 é a sua capacidade de incorporação na membrana celular e, assim, desencadear diversas respostas celulares. Os AG insaturados incorporam-se na posição sn-2 de fosfolipídios da membrana celular de forma competitiva, com graus de afinidade que respeitam a ordem $n-3>n-6>n-9$, influenciando de maneira distinta sua estrutura e a função de diferentes receptores, transportadores, enzimas e canais iônicos a ela relacionados [96]. 


\section{Elongação e dessaturação de AGs n-6 e n-3}

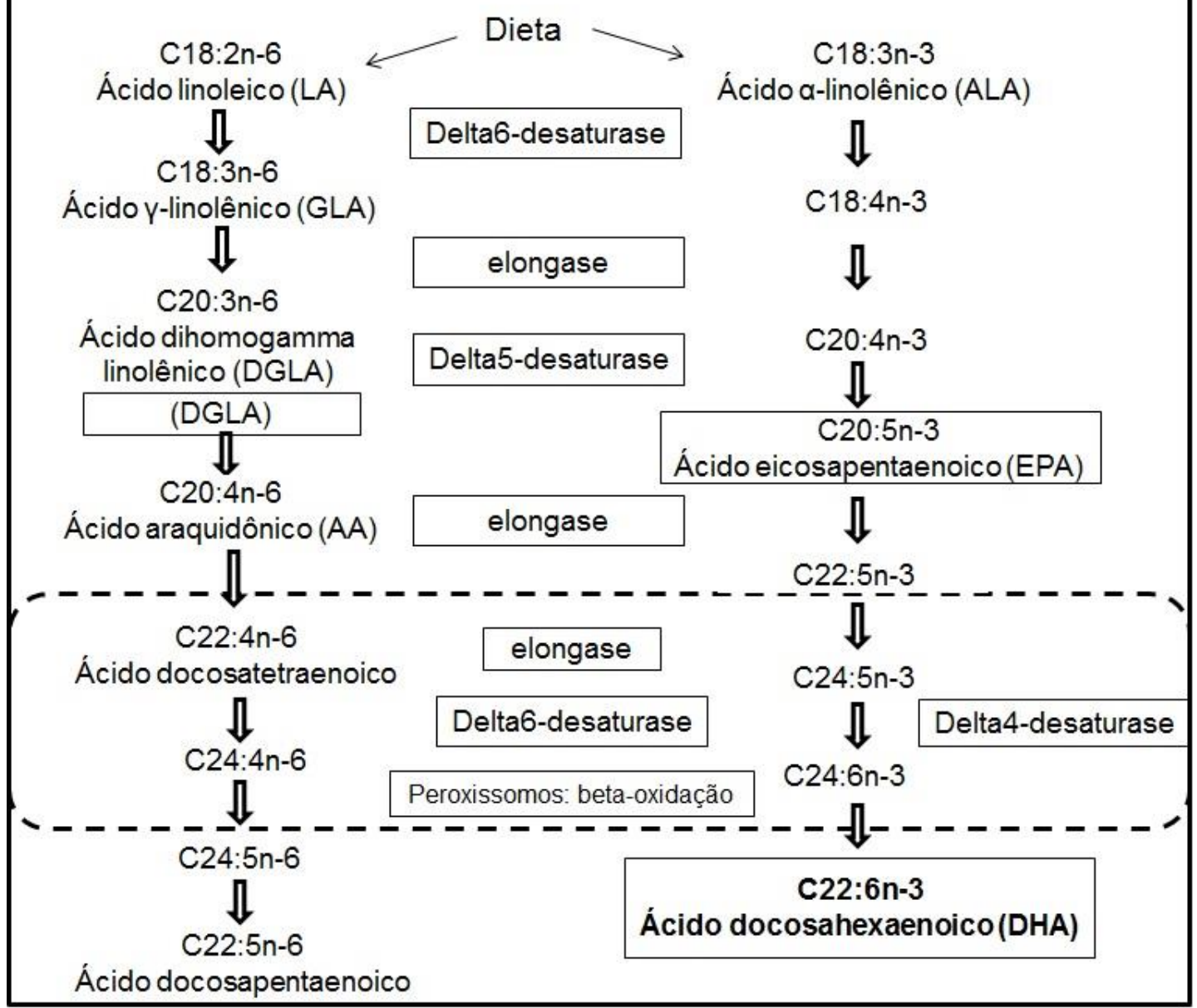

Figura 02: Elongação e dessaturação de AGs n-6 e n3. As enzimas $\Delta 6$ e $\Delta 5$ atuam na dessaturação de ácidos graxos poli-insaturados. Essas reações ocorrem no retículo endoplasmático. A formação do DHA envolve a atuação das enzimas elongase, $\Delta 4$ e $\Delta 6$ dessaturase, que nos peroxissomos sofrem a remoção de dois átomos de carbono. A eficiência global de conversão de ALA é baixa [97]. FONTE: adaptada de Simopoulos, 2008 [95].

Os AG LA e ALA podem ser obtidos a partir de fonte vegetal e animal, porém são encontrados em maiores quantidades nas fontes vegetais. Podese citar os óleos de milho, canola e soja como fontes significativas de AG n-6 e óleo de linhaça e semente de chia como exemplos de fontes vegetais de ALA. Os AG EPA e DHA, por sua vez, podem ser encontrados em alimentos de origem marinha, como óleo de microalga, óleo de peixe, salmão, sardinha, arenque e cavalinha [95]. 
Observações epidemiológicas sugerem que o aumento da ingestão de óleo de peixe, principal fonte de ácidos graxos ômega 3 ( $A G n-3)$, pode estar associado à redução da incidência do câncer de mama [28, 98]. Estudos experimentais têm observado que AGs n-3 podem suprimir a formação e o crescimento de câncer de mama em modelos animais [22-24]. Uma série de mecanismos têm sido propostos para as ações anticâncer dos AG n-3, incluindo a supressão de transformação neoplásica, inibição da proliferação celular, aumento da apoptose e antiangiogênese [26-29, 98].

Especificamente em câncer de mama, estudos experimentais mostram que AG n-3 são capazes de diminuir proliferação e induzir morte celular de diferentes linhagens de células tumorais. Apesar do mecanismo exato ainda ser obscuro, EPA e DHA são capazes de influenciar diretamente proteínas envolvidas nas vias de proliferação, morte e invasão celular [32, 33, 99-103].

Em linhagens celulares de câncer de mama (MDA-MB-231, MCF-7 e HCC2218) tratadas com AG n-3 e n-6, ambas nas doses de $10 \mu \mathrm{M}$, durante seis e 24 horas, verificou-se que 35 genes foram alterados nas primeiras 6 horas de tratamento. Após o tratamento com AG n-3 houve superexpressão do gene DUSP2 (Dual specificity phosphatase 2) que codifica proteína envolvida na regulação negativa de proteínas quinases ativadas por mitógeno (MAPK / ERK, SAPK / JNK, p38), regulando a proliferação e diferenciação celular. Outros genes que apresentaram superexpressão após o tratamento com AG n-3 foram: ITGB4 (Integrin, beta 4), considerado um importante biomarcador para terapia do câncer de mama, regulador de crescimento e sinalização célula-matriz extracelular; SLC26A4 (Solute carrier family 26, member 4), que codifica proteína envolvida no transporte de íons, considerada fator inibidor do crescimento de tecido mamário maligno [104].

Embora os efeitos dos AG n-3, EPA e DHA, sejam semelhantes na maior parte dos estudos, recentes pesquisas demonstram diferenças quando eles são estudados isoladamente. De maneira geral, os estudos experimentais atribuem maior potencial antitumoral ao DHA [32, 33]. 
Em pesquisa realizada em nosso laboratório, LIM 35, do Hospital das Clínicas da Faculdade de Medicina da Universidade de São Paulo, verificou-se que, na comparação entre EPA e DHA, o DHA tem maior potencial antitumoral. $O$ aumento da concentração de DHA na membrana da linhagem celular mamária (HB4aC5.2), com superexpressão de HER-2, , foi capaz de induzir apoptose, alterar a distribuição das células nas fases do ciclo celular e desestruturar os lipid rafts [35]. Ainda em nosso laboratório, verificou-se que o DHA pode alterar a expressão gênica de maneiras distintas dependendo das características celulares, alterando a expressão gênica de vias do metabolismo lipídico de células que hiperexpressam HER-2 e aumentar a expressão de genes supressores tumorais como, por exemplo, SERPINB5, CLDN1 e CDKN1A [105].

Outros estudos experimentais vêm demonstrando a ação do DHA na reativação de genes supressores tumorais como $B R C A 1$ e $B R C A 2$ [36], e o PTEN [37], que sofrem influencia da regulação epigenética. Isso sugere que - DHA possa influenciar vias que controlam eventos epigenéticos de reativação gênica.

Pouco se sabe a respeito da influência de DHA em eventos epigenéticos. Dimri e colaboradores [106] relataram os efeitos dos AG n-3, incluindo o DHA, sobre eventos epigenéticos, de modificações pós traducionais em histonas. Os autores avaliaram a EZH2 (Enhancer of Zeste Homologue 2), proteína que induz trimetilação de histona 3 lisina 27 (H3K27me3), levando à compactação da cromatina e silenciamento de genes supressores tumorais importantes. Após o tratamento com $80 \mu \mathrm{M}$ de DHA por 8 horas, houve diminuição da expressão da EZH2, em linhagens celulares de câncer de mama, MDA-MB-231, com consequente diminuição de sua capacidade invasiva [106]. Isto indicou que o DHA pode agir por meio epigenético em câncer.

Portanto, torna-se de interesse avaliar o envolvimento do DHA em eventos epigenéticos em distintas linhagens de câncer de mama experimental. O resultado de nossas observações poderia contribuir para informações relevantes na compreensão de mecanismos de controle da carcinogênese modificados pelo DHA e seu potencial uso clínico. 


\subsection{Geral}

Verificar a ação do ácido docosahexaenoico (DHA) na modulação de mecanismos epigenéticos em linhagens celulares de carcinoma mamário humano.

\subsection{Específicos}

- Avaliar se o DHA pode induzir modificações pós traducionais em histonas, especificamente em marcas de ativação transcricional, como H3K9ac e H4K16ac, em células MCF-7, MDA-MB-231 e SKBR-3 de carcinoma mamário humano.

- Avaliar se o DHA pode induzir modificações pós traducionais em histonas, especificamente em marcas de repressão transcricional, como H3K9me3 e H3K27me3, em células MCF-7, MDA-MB-231 e SKBR-3 de carcinoma mamário humano.

- Avaliar se o DHA pode alterar a expressão do gene supressor tumoral RASSF1A em células MCF-7, MDA-MB-231 e SKBR-3 de carcinoma mamário humano.

- Avaliar se o DHA pode alterar o padrão de metilação da região promotora de RASSF1A em células MCF-7, MDA-MB-231 e SKBR-3 de carcinoma mamário humano.

- Avaliar se o DHA pode alterar a expressão dos genes DNMT1, DNMT3A, DNMT3B que codificam para enzimas indutoras de metilação do DNA em células MCF-7, MDA-MB-231 e SKBR-3 de carcinoma mamário humano. 
4 MÉTODOS 


\subsection{Comitê de Ética}

O presente trabalho foi submetido e aprovado pelo Comitê de Ética em Pesquisa da Faculdade de Medicina da Universidade de São Paulo (CEP-FMUSP) (protocolo ํㅜ 087/11).

Trabalho realizado no laboratório de Nutrição e Cirurgia Metabólica do Aparelho Digestivo, LIM-35, Laboratório de Oncologia Experimental, LIM-24 e Laboratório de Dieta, Nutrição e Câncer da Faculdade de Ciências Farmacêuticas da Universidade de São Paulo.

\subsection{Cultura Celular}

As linhagens celulares foram adquiridas da American Type Culture Collection (ATCC): MDA-MB-231 (HTB-26 ${ }^{\mathrm{TM}}$ ), MCF-7 (HTB-22 ${ }^{\mathrm{TM}}$ ), SK-BR-3 $\left(\mathrm{HTB}-30^{\mathrm{TM}}\right)$. A linhagem MDA-MB-231 foi cultivada em meio Leibovitz's contendo soro fetal bovino a 10\%, ampicilina, estreptomicina e incubadas a $37^{\circ} \mathrm{C}$, em atmosfera de $100 \%$ e sem $\mathrm{CO}_{2}$ [107]. As células SKBR-3 foram mantidas em meio RPMI 1640 (Gibco), acrescido de 10\% de soro fetal bovino, glutamina, ampicilina, estreptomicina e fungizona, sendo incubadas a $37^{\circ} \mathrm{C}$, em atmosfera de $95 \%$ e com $5 \%$ de $\mathrm{CO}_{2}$ [104]. A linhagem de células MCF-7, por sua vez, foram mantidas em meio DMEM (Dubelcco's Modified Eagle's Medium), acrescido de $10 \%$ de soro fetal bovino, ampicilina, estreptomicina e incubadas a $37^{\circ} \mathrm{C}$, em atmosfera de $95 \%$ e com $5 \%$ de $\mathrm{CO}_{2}$ [107]. 


\subsection{Viabilidade celular}

As linhagens foram submetidas à análise de viabilidade celular por teste de exclusão azul de Tripan (“Tripan Blue”, Sigma-EUA). Todos os experimentos foram sendo realizados com amostras que apresentaram viabilidade celular superior a $95 \%$.

\subsection{Tratamento das linhagens com ácido docosahexaenoico (DHA)}

As linhagens celulares foram tratadas durante 72 horas com $100 \mu \mathrm{M}$ de DHA (cis-4,7,10,13,16,19; Sigma) ou etanol (veículo de diluição do DHA). A porcentagem de etanol foi sempre menor que $0,05 \%$ do volume total de meio [100]. A concentração de DHA e o tempo de tratamento foram padronizados em estudos anteriores desenvolvidos em nosso laboratório [35].

A confluência das células nas garrafas foi mantida em torno de $70 \%-80 \%$. Esse controle foi realizado com o objetivo de evitar a ocorrência de alterações na progressão do ciclo decorrentes das condições do próprio ambiente de cultura, como a privação de nutrientes, que pode estar diretamente relacionada ao nível de confluência das células. Foram plaqueadas $2 \times 10^{6}$ células em cada garrafa e após o período de tratamento, as células foram tripsinizadas e ressuspendidas em $6 \mathrm{ml}$ de meio de cultura. Cerca de $1 \times 10^{6}$ células foram distribuídas em 3 tubos, sendo um micro-tubo de $2 \mathrm{ml}$ (para extração imediata de RNA total, conforme descrito a seguir), outras duas em tubo criogênico, em que após a lavagem com PBS, e acréscimo de $500 \mathrm{ml}$ de PBS ao precipitado celular obtido, as amostras foram armazenadas em nitrogênio líquido até o momento da extração de DNA (tubo criogênico 1) e proteínas totais (tubo criogênico 2). Com isso, a 
extração de RNA, DNA e proteínas totais foram realizadas a partir da mesma garrafa de células cultivadas, para que as análises pudessem ser realizadas de maneira mais homogênea.

\subsection{Avaliação das modificações pós traducionais em histonas}

A técnica de western blot foi utilizada para avaliar o padrão de acetilação no resíduo de lisina 9 da histona 3 (H3K9ac) e no resíduo de lisina 16 da histona 4 (H4K16ac), bem como a trimetilação no resíduo de lisina 9 da histona 3 (H3K9me3) e no resíduo de lisina 27 da histona 3 (H3K27me3).

Para extração de histonas, cerca de $8 \times 10^{6}$ células $/ \mathrm{ml}$ foram plaqueadas e tratadas com as condições padronizadas. As células foram homogeneizadas com $600 \mu \mathrm{L}$ de tampão de lise gelado (Tris $10 \mathrm{mM}$; Bissulfito de sódio 50mM; Triton X 100 1\%; MgCl2 10mM; sacarose 8,6\%, PMSF; $\mathrm{pH}=6,5)$ por 1-2 minutos e centrifugado por 15 minutos a $700 \mathrm{~g}$ e $4^{\circ} \mathrm{C}$. O precipitado foi lavado com $50 \mu \mathrm{L}$ de tampão Tris-EDTA (Tris $10 \mathrm{mM}$; EDTA 13 mM; PMSF; pH=8,0) e ressuspenso com 150 $\mu \mathrm{L}$ de água ultra-pura e $100 \mu \mathrm{L}$ de $\mathrm{H}_{2} \mathrm{SO}_{4} 0,8 \mathrm{~N}$, e incubado por uma noite a $4^{\circ} \mathrm{C}$. Após este período, foi centrifugado por 15 minutos a $10.000 \mathrm{~g}$ e $4^{\circ} \mathrm{C}$, e o sobrenadante foi incubado com $1 \mathrm{~mL}$ de acetona a $-20^{\circ} \mathrm{C}$ por uma noite para precipitação das histonas. Posteriormente, foi acrescentado $10 \mu \mathrm{L}$ de $\mathrm{NaOH} 3 \mathrm{~N}$ para neutralização do precipitado, que foi submetido a centrifugação por 5 minutos a $12000 \mathrm{~g} \mathrm{e} 4^{\circ} \mathrm{C}$. O precipitado foi ressuspenso em $20 \mu \mathrm{L}$ de tampão de carregamento (uréia 5,8M; ácido acético glacial 0,9M; glicerol 16\%; 2-mercaptoetanol $4,8 \%$ e verde de metila $0,2 \%$ ). As amostras foram normalizadas utilizando-se o reagente Bradford (BioRad) e a curva padrão de albumina (0 a $5000 \mu \mathrm{g} / \mathrm{mL}$ ). Todos os pontos de concentração de cada 
grupo foram realizados em duplicata e os dados geraram uma curva padrão para cada concentração analisada foram determinados em triplicata Utilizou-se cerca de $30 \mu \mathrm{g} / \mathrm{\mu L}$ de proteína total ou histonas para cada canal. A quantificação foi realizada em leitor de Elisa, no comprimento de onda de $595 \mathrm{~nm}$ e as amostras armazenadas a $-80^{\circ} \mathrm{C}$.

As histonas extraídas foram submetidas à eletroforese em gel de poliacrilamida desnaturante (SDS-PAGE) a 15\% e tampão Tris-glicina 1X, utilizando-se uma cuba de eletroforese vertical (Mini PROTEAN®System, Bio Rad, EUA). Posteriormente, as proteínas foram transferidas do gel para a membrana de nitrocelulose Hybond-ECLTM (Amersham Biosciences, EUA), com poro de diâmetro de $0,20 \mu \mathrm{m}$, no decorrer de 35 minutos. Para verificar a eficácia da transferência, a membrana foi corada com Ponceau-S (USB, EUA) e em seguida, lavada com PBS e água.

O bloqueio da membrana foi realizado com reagente próprio presente no sistema de quimioluminescência ECL (Enhanced Chemiluminescence, GE Heathcare, Reino Unido), diluído em PBS ( $1 \mathrm{~mL}$ de PBS para cada $20 \mathrm{mg}$ de ECL) e incubada por 1 hora em temperatura ambiente, sob agitação. Após o bloqueio, a membrana foi incubada com o anticorpo primário antiacetil histona H3K9 ou anti-acetil histona H4K16 (Upstate, EUA) (1:5000) ou anticorpo anti-H3K9me3 ou anti-H3K27me3 (1:700; Cell Signaling Technology), diluído em reagente $\mathrm{ECL}$, por uma noite a $4^{\circ} \mathrm{C}$. Posteriormente, a membrana foi incubada com anticorpo secundário conjugado a peroxidase HRP antiimunoglobulina de coelho (GE Healthacare, Reino Unido) na diluição 1:10000 em reagente ECL por 1 hora.

A membrana foi então incubada com anticorpo primário anti-histona $\mathrm{H} 1$ (Upstate, EUA) na diluição de 1:5000 em reagente ECL por $1 \mathrm{~h}$ à $37^{\circ} \mathrm{C} e$ sob agitação, a qual serviu para controle da técnica. Em seguida, a membrana foi incubada com anticorpo secundário conjugado a peroxidase HRP anti-imunoglobulina de rato (GE Healthacare, Reino Unido) na diluição 1:10000 em ECL por $1 \mathrm{~h}$, a $37^{\circ} \mathrm{C}$ e sob agitação. A imunodetecção foi feita utilizando-se o sistema de quimioluminescência ECL. O sinal foi captado 
utilizando o sistema de aquisição de imagens ImageQuant 400 (GE Healthcare, Reino Unido). Os resultados foram obtidos a partir de três diferentes ensaios independentes e foram submetidos à análise estatística t de Student, considerando nível de significância de $p \leq 0,05$.

\subsection{Análise da expressão gênica por PCR em tempo real do gene RASSF1A}

- Extração do RNA total: A extração do RNA total a partir de $1 \times 10^{6}$ células foi realizada de acordo com instruções do Kit illustra RNAspin Mini RNA Isolation (GE Healthcare, Alemanha). A quantificação, ou seja, a concentração do RNA total foi obtida pela leitura da absorbância nos comprimentos de onda de 260 e $280 \mathrm{nM}$ pelo espectrofotômetro NanoDrop (Nanodrop1000, ThermoScientific), sendo a pureza avaliada pela razão 260/280. Foram consideradas amostras de pureza aceitável quando os valores dessa razão se situaram entre 1.8 e 2.1. A integridade do RNA foi avaliada por meio do aparelho de eletroforese por microcapilaridade, Bioanalyzer (Model 2100; Agilent Technologies, CA) ou por eletroforese com gel de agarose a 0,8\%.

- Síntese de cDNA: Para a síntese de cDNA foi utilizado o protocolo de transcrição reversa High Capacity RNA-to-cDNA (Applied Biosystems), conforme as orientações do fabricante. Foi utilizado até $27 \mu \mathrm{L}$ de RNA total $(33,33 \mathrm{ng} / \mu \mathrm{L})$ para cada $60 \mu \mathrm{l}$ de reação. O volume da reação foi ajustado de acordo com o desenho experimental, mantendo constantes as concentrações de cada componente. Os componentes da reação foram 30 $\mu \mathrm{L}$ de RT buffer, $3 \mu \mathrm{L}$ de enzyme mix, $\mathrm{H}_{2} \mathrm{O}$ Nuclease-free suficiente para completar $60 \mu \mathrm{L}$. As condições de termociclagem foram no primeiro passo uma temperatura de $37^{\circ} \mathrm{C}$ durante 60 minutos, segundo passo em $95^{\circ} \mathrm{C}$ durante 5 minutos e, por fim, o último passo o resfriamento em $4^{\circ} \mathrm{C}$. 
- PCR em tempo real: Para a realização do PCR em tempo real foi utilizado o sistema de amplificação TaqMan PCR master mix (Applied Biosystems), a partir de 50ng de cDNA. Foram selecionados iniciadores e sondas marcadas com fluoróforo FAM de acordo com os AssaylD do gene RASSF1A (Hs00200394_m1) disponibilizado pela Applied Biosystems (www.appliedbiosystems.com.br). Para a análise da expressão dos genes DNMT1, DNMT3A e DNMT3B a reação de RT-PCR em tempo real foi realizada utilizando SYBR Green ${ }^{\circledR}$ Real-Time PCR Master Mix (Applied Biosystems). Os primers foram desenhados com Primer-Blast software (http://www.ncbi.nlm.nih.gov/tools/primer-blast/) e sintetizados pela IDT (Integrated DNA Technologies), com as seguintes sequências:

\begin{tabular}{|l|l|l|}
\hline DNMT1 sentido & TAC CTG GAC GAC CCT GAC CTC & \multirow{2}{*}{$103 \mathrm{pb}$} \\
\hline DNMT1 anti-sentido & CGT TGG CAT CAA AGA TGG ACA & \\
\hline DNMT3A sentido & TAT TGA TGA GCG CAC AAG AGA GC & \multirow{2}{*}{$111 \mathrm{pb}$} \\
\hline DNMT3A anti-sentido & GGG TGT TCC AGG GTA ACA TTG AG & \\
\hline DNMT3B sentido & GGC AAG TTC TCC GAG GTC TCT G & \multirow{2}{*}{$113 \mathrm{pb}$} \\
\cline { 1 - 2 } DNMT3B anti-sentido & TGG TAC ATG GCT TTT CGA TAG GA & \\
\cline { 1 - 2 }
\end{tabular}

As reações foram realizadas em triplicata no aparelho $A B I$ Prism ${ }^{\circledR}$ 7900 Sequence Detection System (Applied Biosystems) em placas de 96 wells - MicroAmp® Optical (Applied Biosystems). A reação de PCR foi iniciada a $50^{\circ} \mathrm{C}$ por 2 minutos, seguida de $95{ }^{\circ} \mathrm{C}$ por 10 minutos e a amplificação conduzida por 50 ciclos de $15 \mathrm{~s}$ a $95^{\circ} \mathrm{C}$ e 1 minuto a $60^{\circ} \mathrm{C}$. O sinal de fluorescência captada pelo software do aparelho, que gerou o parâmetro ciclo, denominado ciclo treshold (Ct), momento em que a amplificação acontece de forma exponencial. Para cada amostra de cDNA, o $\mathrm{Ct}$ de cada gene foi registrado e comparado com o do gene controle GAPDH (Hs03929097, Applied Biosystems), que foi utilizado como controle endógeno. Os cálculos de normalização das amostras foram realizados pelo software do aparelho, sendo que a média dos valores da expressão relativa 
de cada triplicata foram normalizados pelos valores da expressão do controle endógeno (GAPDH) para obtenção do valor do $\Delta \mathrm{Ct}[\Delta \mathrm{Ct}=\mathrm{Ct}($ alvo)$\mathrm{Ct}($ endógeno)]. Os resultados $(\Delta \mathrm{Ct})$ foram utilizados para o cálculo das diferenças dos valores da expressão entre cada amostra e o calibrador, obtendo-se, assim, os valores de $\Delta \Delta$ Ct. O método $2^{-\Delta \Delta \mathrm{Ct}}$ recomendado por Livak e Schmittgen[108] foi utilizado para o cálculo da expressão relativa do gene RASSF1A. Os resultados foram apresentados em gráficos de boxplot, sendo utilizados testes não paramétricos para verificar a significância das diferenças. $O$ nível de significância foi bicaudado e $p \leq 0,05$. Foi utilizado o programa estatístico SPSS - Statistical Package for the Social Sciences, versão 11.0 (SPSS Inc., Chicago, IL, EUA) para as análises.

\subsection{Análise do Padrão de Metilação do Promotor do Gene RASSF1A pela Técnica da Reação em Cadeia da Polimerase Específica para Metilação (MS-PCR)}

A técnica MS-PCR (Methylation Specific PCR) consiste em uma das técnicas mais utilizadas para avaliar o padrão de metilação no promotor de genes específicos. Com base no princípio da modificação do DNA induzida pelo bissulfito de sódio, que converte apenas os resíduos de citosinas não metiladas em uracilas (citosinas metiladas permanecem inalteradas), a sequência sob investigação é amplificada por PCR com dois conjuntos de iniciadores ("primers") específicos.

- Extração de DNA das linhagens celulares: A extração de DNA foi realizada pelo método clássico utilizando fenol-clorofórmio e álcool isoamílico. As células foram incubadas com 500 $\mu$ de solução de lise TES (Tris $\mathrm{HCl} 10$ $\mathrm{mM}$ pH 8.0, EDTA $50 \mathrm{mM}$, SDS 0,5\%) acrescidos de $5 \mu \mathrm{l}$ de RNAse A (20 $\mathrm{mg} / \mathrm{ml})$ e $5 \mu \mathrm{l}$ de Proteinase $\mathrm{K}(20 \mathrm{mg} / \mathrm{ml})$ sob agitação, por 
aproximadamente 18 horas a $55^{\circ} \mathrm{C}$. Em seguida, foi adicionado $500 \mu \mathrm{l}$ de fenol-clorofórmio-álcool isoamílico (25:24:1), e agitados por 5 min em agitador mecânico. Posteriormente, foi realizada uma centrifugação a $4^{\circ} \mathrm{C}$ por 30 minutos a $3000 \mathrm{rpm}$ para separar a fase aquosa da fase orgânica. A fase aquosa foi, então, transferida para um tubo de microcentrífuga (Phase Lock Gel Heavy, Eppendorf, Alemanha), e foi realizada uma nova extração com clorofórmio-alcool isoamílico (24:1). Após nova centrifugação, a fase aquosa foi novamente transferida para outro tubo onde foi adicionado acetato de sódio $3 \mathrm{M}$ e etanol gelado $100 \%$ e incubado por 2 dias a $-80^{\circ} \mathrm{C}$ para que ocorra a precipitação do DNA. Após centrifugação por 30 minutos a $12000 \mathrm{rpm}$, o sobrenadante foi desprezado cuidadosamente e foi adicionado etanol a $70 \%$ para lavar as impurezas eventualmente presentes. Foi realizada uma nova centrifugação por 10 minutos e o sobrenadante novamente desprezado. $O$ preciptado foi ressuspenso em 50 ul de TE (Tris 100 mM, EDTA 10 mM, pH =8,0). Após quantificação do DNA em espectrofotômetro (Nanodrop1000, ThermoScientific), sua integridade foi verificada em gel de agarose a $0,8 \%$.

- Modificação do DNA com Bissulfito de Sódio: Cerca de $2 \mu \mathrm{g}$ do DNA genômico, juntamente com DNA de esperma de salmão ( $\mathrm{Ci}-10 \mathrm{mg} / \mathrm{ml}$ ) (Eppendorf, Alemanha) em um volume final de $17 \mu \mathrm{l}$ foram desnaturados com $\mathrm{NaOH}$ (concentração final de $0,2 \mathrm{M}$ ) por 20 min. a $50^{\circ} \mathrm{C}$. Paralelamente, foi preparada uma solução de bissulfito de sódio 2,5 M/ hidroquinona $1 \mathrm{M}, \mathrm{pH} 5$ que foi adicionada à amostra e incubada a $70^{\circ} \mathrm{C}$ por $3 \mathrm{~h}$, no escuro. O DNA modificado foi purificado com o sistema Wizard DNA- Clean-up System (Promega, EUA), tratado com NaOH (concentração final $0,3 \mathrm{M}$ ) por 10 min e então preciptado com acetato de amônio $5 \mathrm{M}$, etanol gelado e $1 \mu \mathrm{l}$ de glicogênio $(20 \mathrm{mg} / \mathrm{ml})$ durante uma noite à $-20^{\circ} \mathrm{C}$. Após esse período, o DNA foi centrifugado por 15 minutos a $20.817 \mathrm{~g}$, o sobrenadante desprezado e foi adicionado $500 \mu \mathrm{l}$ de etanol a $70 \%$. Foi realizada uma nova centrifugação e o sobrenadante foi novamente descartado. O precipitado seco foi ressuspendido em $50 \mu \mathrm{l}$ de TE e, em seguida, armazenado a $-80^{\circ} \mathrm{C}$ até o momento de seu uso. 
A reação de amplificação por PCR ocorreu nas seguintes condições: incubação de 15 minutos a $95^{\circ} \mathrm{C}$, seguida de 40 ciclos de desnaturação de 30 segundos a $94^{\circ} \mathrm{C}, 50$ segundos a uma temperatura de anelamento $\left(64^{\circ} \mathrm{C}\right.$ para molde metilado e $59^{\circ} \mathrm{C}$ para o molde não metilado), 30 segundos a $72^{\circ} \mathrm{C}$ e, finalmente a $72{ }^{\circ} \mathrm{C}$ por 10 minutos. Os produtos da PCR foram separados em gel de agarose $2 \%$ corado com BlueGreen (LGC Biotecnologia). Foi utilizado o EpiTect Control DNAs (Qiagen), pronto para uso, para controle positivo e negativo dos primers para as sequências metiladas e não metiladas.

- Amplificação por PCR: Os iniciadores do gene RASSF1A foram os seguintes, de acordo com Burbee et al.[109]:

Sequência metilada:

5'-GGGTTTTGCGAGAGCGCG-3'(sentido)

5'-GCTAACAAACGCGAACCG-3'(anti-sentido),

Sequência não metilada:

5'-GGTTTTGTGAGAGTGTGTTTAG-3' (sentido)

5'-CACTAACAAACACAAACCAAAC-3' (anti-sentido)

\subsection{Ensaio de morte e ciclo celular}

Após os tratamentos nas condições apresentadas, as células $\left(1 \times 10^{5}\right)$ foram tripsinizadas, fixadas em etanol $70 \%$ e mantidas congeladas a $-20^{\circ} \mathrm{C}$ até o momento da análise por citometria de fluxo (citômetro FACScalibur, Becton Dickson). As células foram incubadas por 30 minutos em temperatura ambiente com $20 \mu \mathrm{g} / \mathrm{ml}$ de iodeto de propídio (PI) $(100 \mu \mathrm{g} / \mathrm{ml}-$ Sigma-Aldrich), triton $(0,1 \% \mathrm{v} / \mathrm{v})$ e $200 \mu \mathrm{g} / \mathrm{ml}$ de RNAse (DNAse-free) em PBS. O processo de morte e as fases do ciclo celular foram avaliados em 
$1 \times 10^{5}$ células de cada amostra pela incorporação estequiométrica de iodeto de propídio ao DNA, permitindo quantificação relativa do conteúdo de DNA no citômetro de fluxo. Células apresentando quantidade de DNA inferior a 2n (hipodiplóides $=\mathrm{H} 0$ ) foram consideradas em morte celular. As células apresentando quantidades de DNA $2 n$ e $4 n$ foram consideradas nas fases G0/G1 e S/G2/M do ciclo celular, respectivamente. Os resultados, obtidos a partir de três diferentes ensaios em triplicata, foram submetidos à análise estatística t de Student, considerando nível de significância de p $\leq 0,05$. 


\subsection{Acetilação no resíduo de lisina 9 da histona 3 (H3K9ac) e no resíduo 16 da histona 4 (H4K16ac)}

$\mathrm{O}$ tratamento com DHA não afetou a acetilação em H3K9 na linhagem celular MDA-MB-231, mas demonstrou tendência não significativa de aumentar a acetilação H3K9 nas linhagens MCF-7 e SKBR-3, conforme observamos na figura 3. Em relação ao controle etanol, o tratamento com DHA promoveu aumento significativo da acetilação em H4K16, nas linhagens MCF-7 ( $p=0,04)$ e MDA-MB-231 ( $p=0,03)$, mas não afetou a acetilação da linhagem SKBR-3, como pode-se observar na figura 3. 
(A)

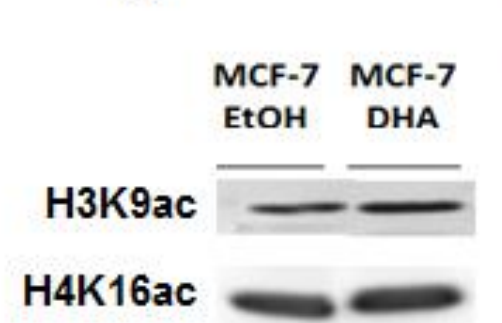

H1
(B)

MDA- MDA-

MB-231 MB-231

(C)

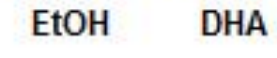
SKBR3 SKBR3
EtOH DHA
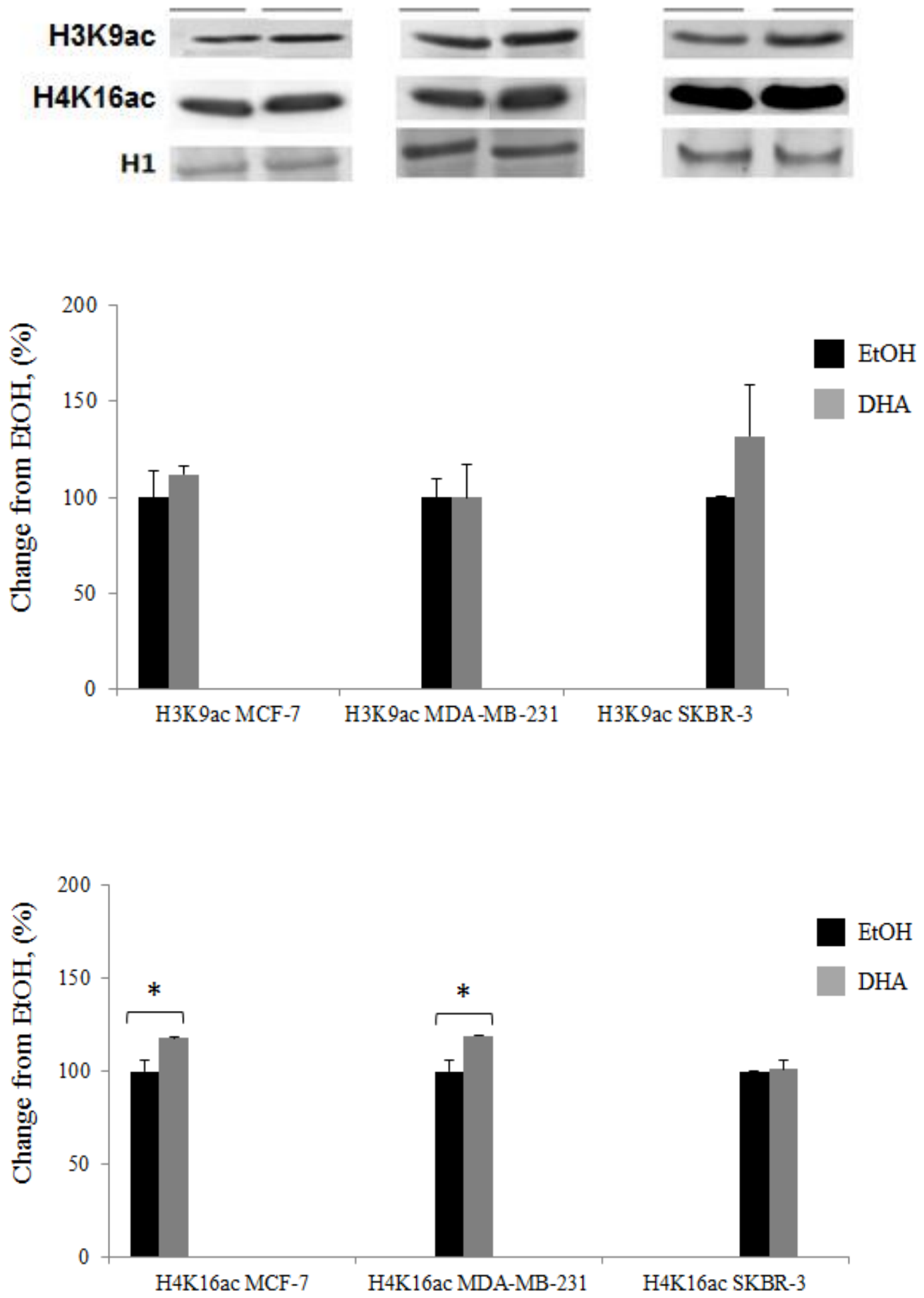

$\mathrm{EtOH}$

DHA

Figura 3: Representações de três ensaios independentes da análise de acetilação no resíduo de lisina 9 histona 3 (H3K9ac) e no resíduo 16 histona 4 (H4K16ac) nas linhagens MCF-7, MDA-MB-231 e SKBR-3. EtOH: grupo controle. DHA: grupo tratado; tratamento com $100 \mu \mathrm{M}$ de DHA por 72h. (A): Linhagem MCF-7; (B): Linhagem MDA-MB-231; (C): Linhagem SKBR-3. ${ }^{*} \mathrm{p}<0,05$. 


\subsection{Trimetilação no resíduo de lisina 9 da histona 3 (H3K9me3) e no resíduo 27 da histona 3 (H3K27me3)}

A figura 4 ilustra os resultados da trimetilação no resíduo de lisina 9 da histona 3 (H3K9me3) e no resíduo 27 da histona 3 (H3K27me3) após o tratamento com $100 \mu \mathrm{M}$ de DHA ou controle durante 72h. Após o tratamento com DHA observamos que a H3K9me3 foi parcialmente inibida nas linhagens MDA-MB-231 e SKBR-3, mas sem significância estatística ( $p>0,05)$. Em comparação ao controle, encontramos também diminuição dos níveis de H3K27me3, nas três linhagens estudadas, sendo mais visível na linhagem SKBR-3, porém sem significado estatístico ( $p>0,05)$, conforme se observa na figura 4. 
(A)

(B)

(C)

MDA-MB- MDA-MB-
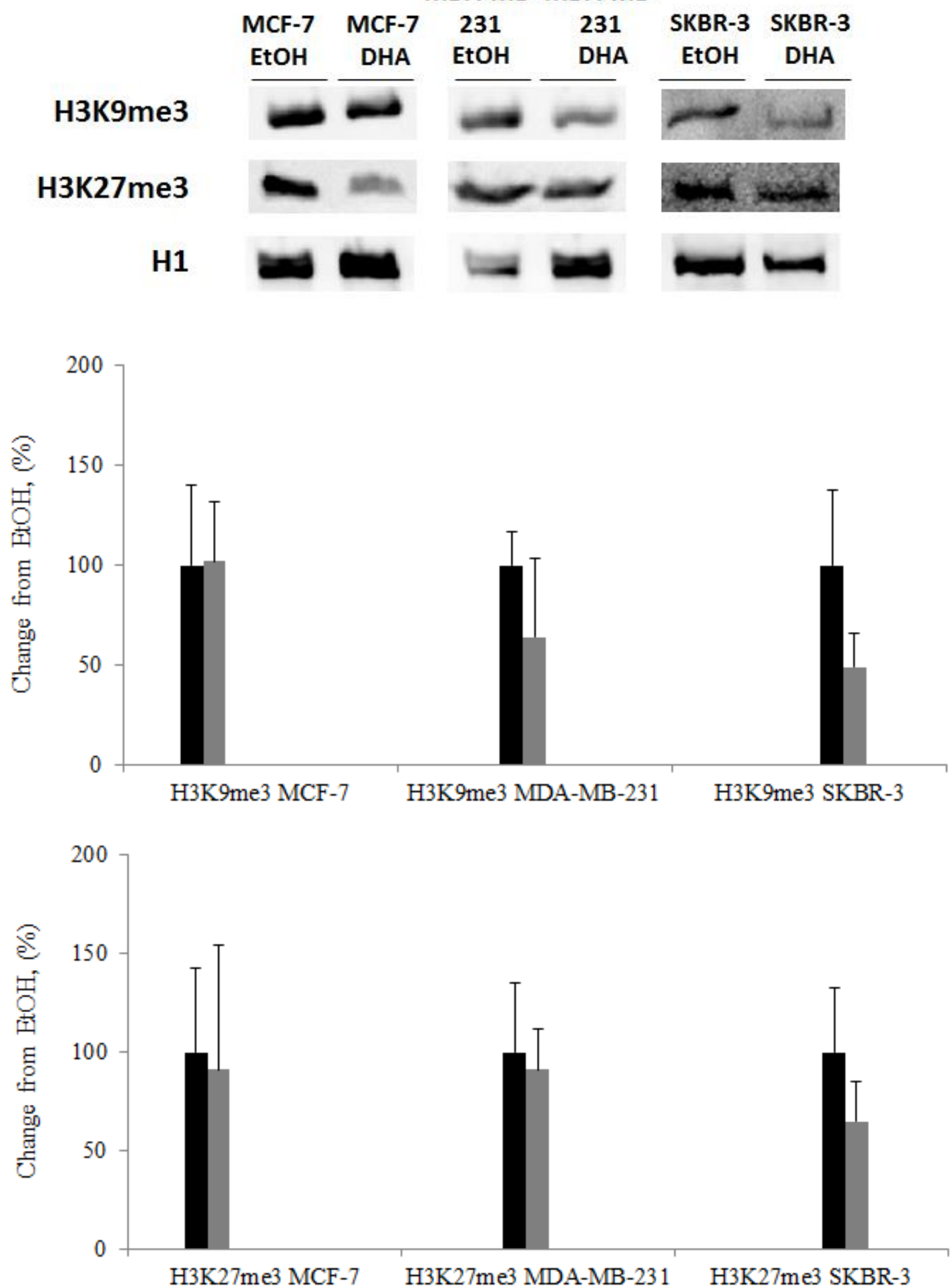

Figura 4: Representações de três ensaios independentes da análise de trimetilação no resíduo de lisina 9 histona 3 (H3K9me3) e no resíduo 27 histona 3 (H3K27me3) nas linhagens MCF-7, MDA-MB-231 e SKBR-3. EtOH: grupo controle. DHA: grupo tratado; tratamento com $100 \mu \mathrm{M}$ de DHA por 72h. (A): Linhagem MCF-7; (B): Linhagem MDA-MB231; (C): Linhagem SKBR-3. 


\subsection{Expressão do gene RASSF1A por RT-qPCR}

Após o tratamento com DHA observou-se aumento significativo da expressão do gene RASSF1A na linhagem MCF-7 (fold change = 1,98; $p=0,03$ ) em relação ao controle etanol. No entanto, não houve aumento da expressão desse gene nas linhagens MDA-MB-231 e SKBR-3 em relação ao controle $(p>0,05)$. Na figura 5 encontra-se o nível de expressão do gene RASSF1A das três diferentes linhagens (MCF-7, SKBR-3 e MDA-MB-231) tratadas com DHA ou etanol.

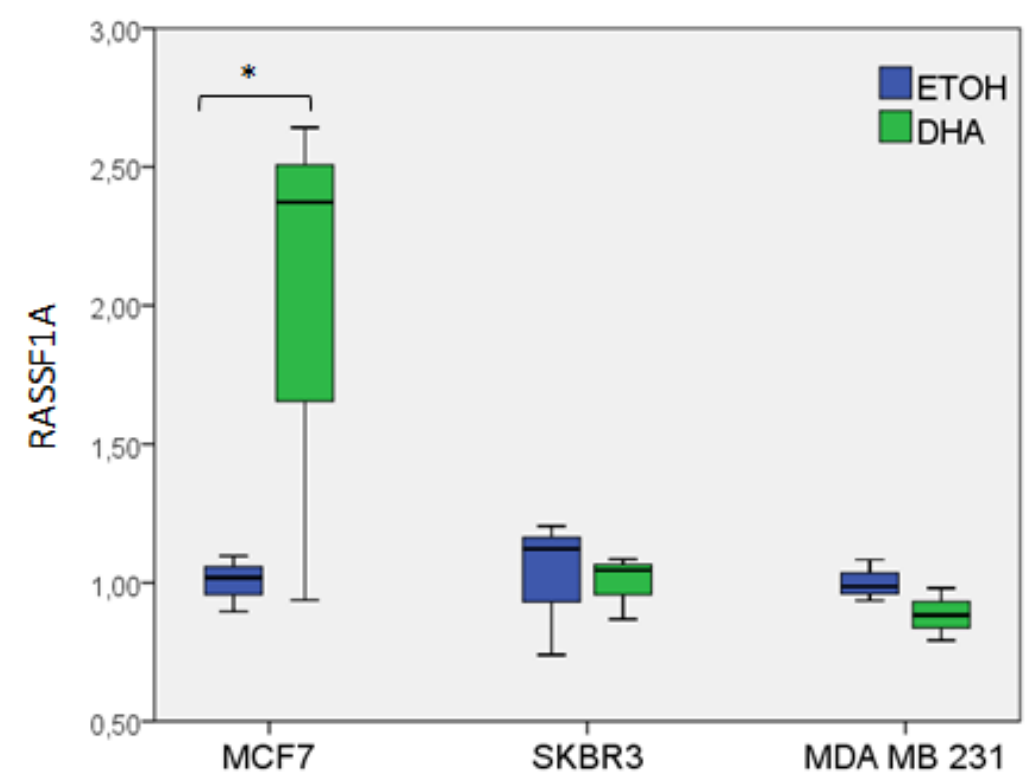

Figura 5: Box plot representativo de três ensaios independentes da expressão relativa do gene RASSF1A por RT-qPCR. ETOH: grupo controle. DHA: grupo tratado; tratamento com $100 \mu \mathrm{M}$ de DHA por $72 \mathrm{~h} .{ }^{*} \mathrm{p}<0,05$ 


\subsection{Padrão de Metilação do Promotor do Gene RASSF1A}

A região promotora analisada do gene RASSF1A apresentou-se predominantemente metilada nas três linhagens estudadas. $O$ tratamento com DHA pareceu induzir desmetilação na linhagem SKBR-3 e MCF-7, mas não na linhagem MDA-MB-231. A figura 6 mostra os resultados qualitativos do padrão de metilação na região promotora do gene RASSF1A nas três diferentes linhagens (MCF-7, SKBR-3 e MDA-MB-231) tratadas com DHA ou etanol.

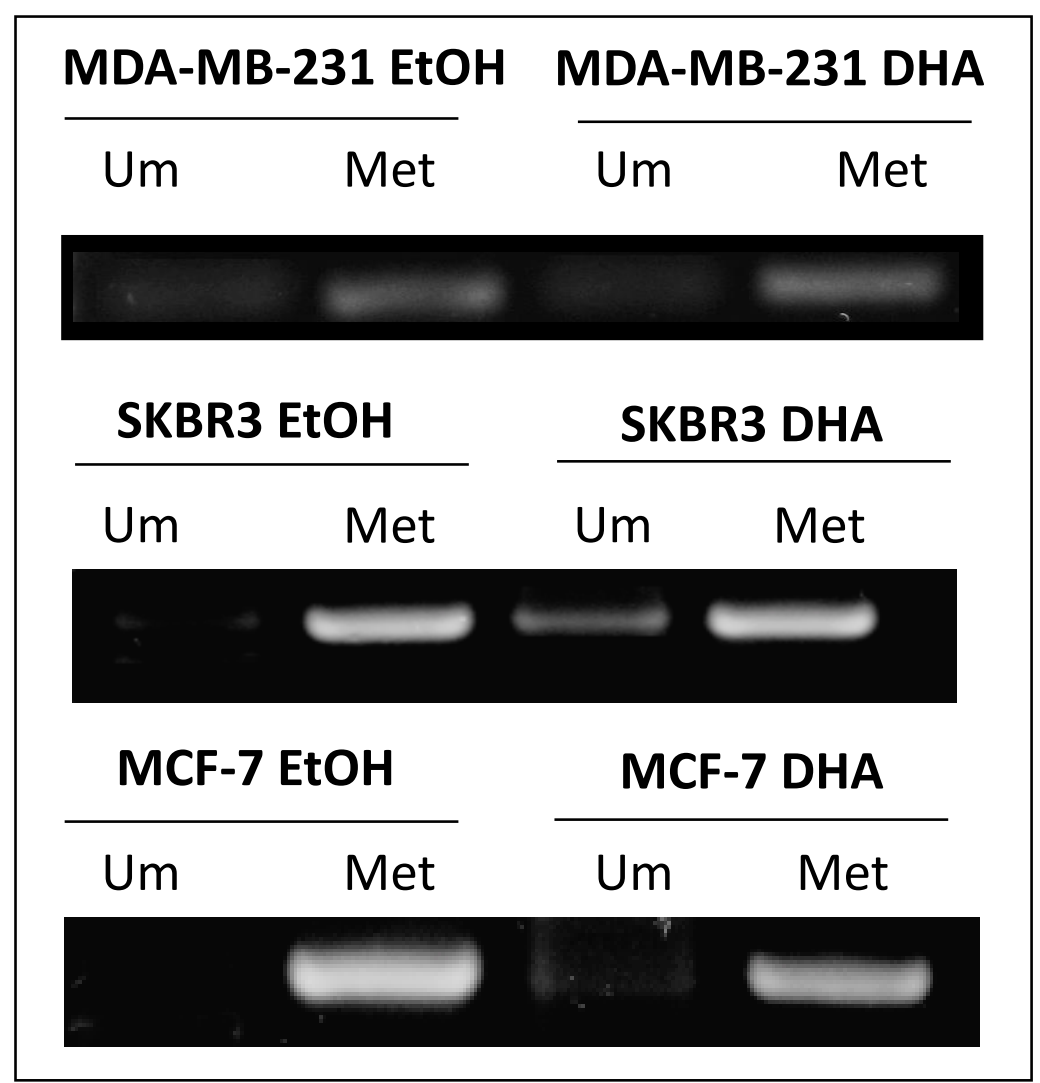

Figura 6: Representação de três ensaios independentes da análise do padrão de metilação da região promotora do gene RASSF1A das linhagens MDA-MB-231, SKBR3 e MCF-7. EtOH: grupo controle. DHA: grupo tratado; tratamento com $100 \mu \mathrm{M}$ de DHA por $72 \mathrm{~h}$. (Um): amplificação com primers específicos para sequência não metilada; (Met): amplificação com primers específicos para sequência metilada. 


\subsection{Expressão dos genes DNMT1, DNMT3A e DNMT3B por RT-qPCR}

A figura 7 mostra os resultados da expressão relativa dos genes DNMT1, DNMT3A e DNMT3B. Após 72h de tratamento com $100 \mu \mathrm{M}$ de DHA não houve diferença estatística, em comparação ao controle etanol, na expressão dos genes DNMT1 e DNMT3B nas três linhagens estudadas, embora tenha sido observada uma tendência para diminuição de DNMT3B na linhagem MDA-MB-231, porém não significativo $(p=0,068)$.
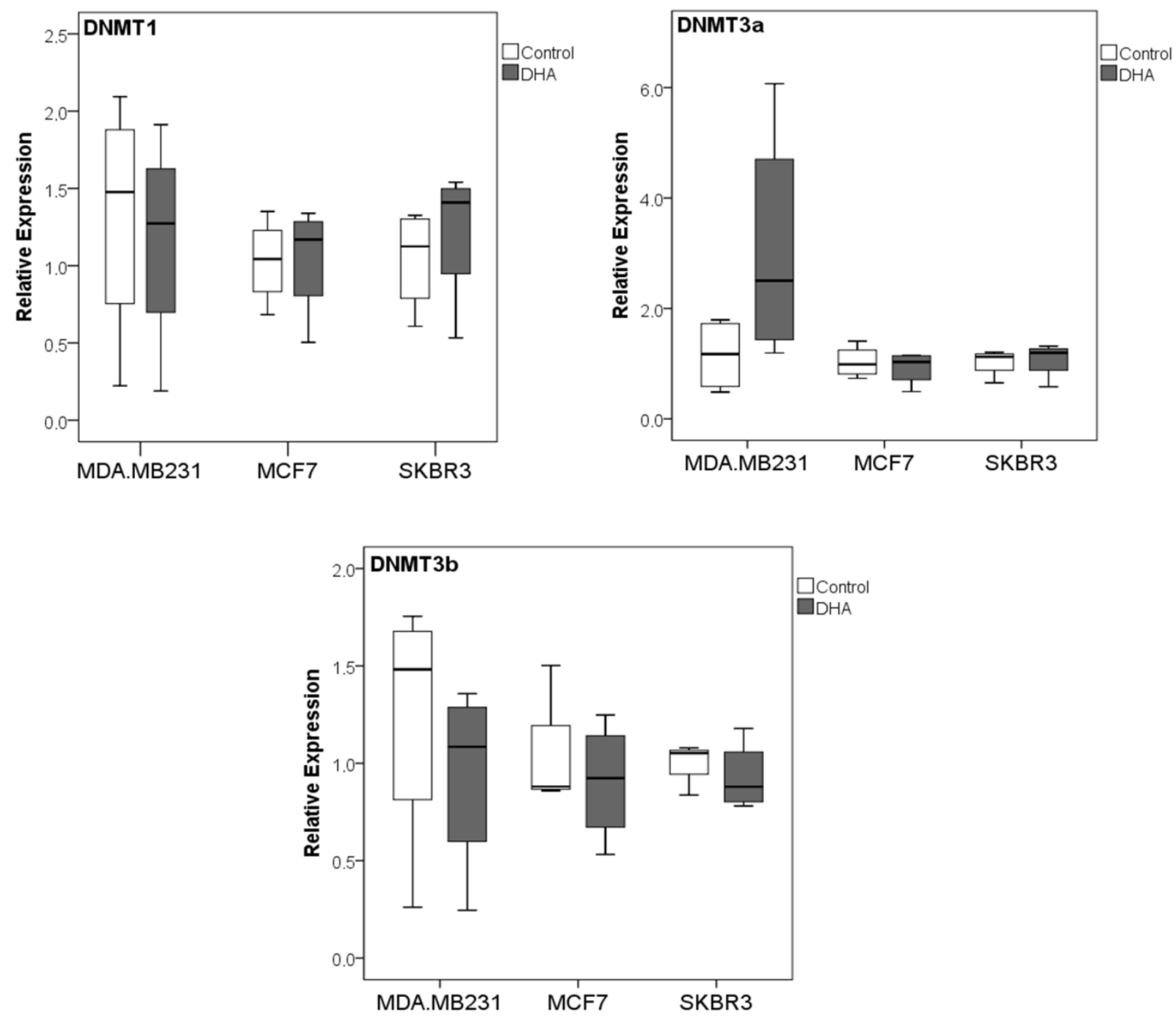

Figura 7: Box plots representativos das expressões relativas dos genes DNMT1, DNMT3A e DNMT3B por RT-qPCR das linhagens MDA-MB-231, MCF-7 e SKBR3. ETOH: grupo controle. DHA: grupo tratado; tratamento com $100 \mu \mathrm{M}$ de DHA por $72 \mathrm{~h}$. 


\subsection{Morte e ciclo celular}

A figura 8 mostra os resultados obtidos para as três linhagens tratadas com DHA e etanol. Células apresentando quantidade de DNA inferior a $2 \mathrm{n}$ (hipodiplóides=H0) foram consideradas em morte celular. As células apresentando quantidades de DNA $2 n$ e $4 n$ foram consideradas nas fases G0/G1 e S/G2/M do ciclo celular, respectivamente. A análise estatística dos histogramas não mostrou diferença significativa na porcentagem de morte e distribuição das células MDA-MB-231, SKBR-3 e MCF-7 nas diferentes fases do ciclo celular após tratamento com DHA ( $p>0,05)$. 
(A)
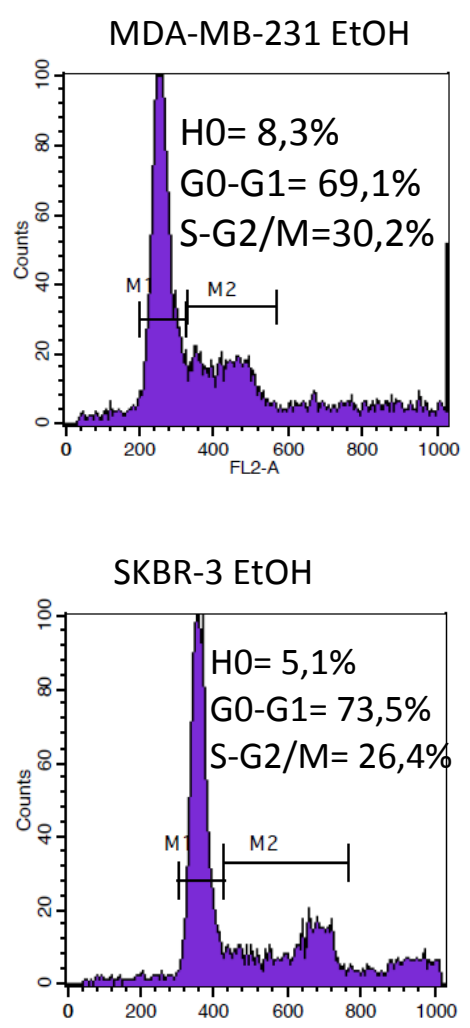

MCF-7 EtOH

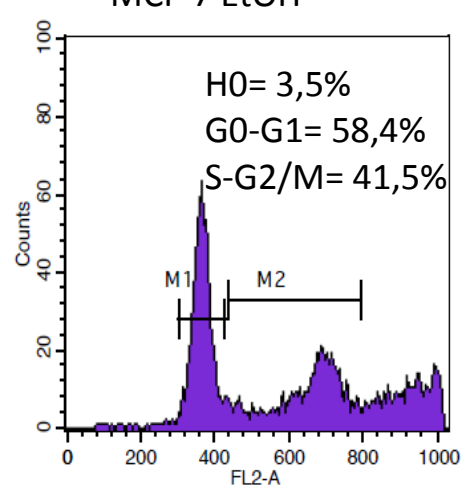

(B)
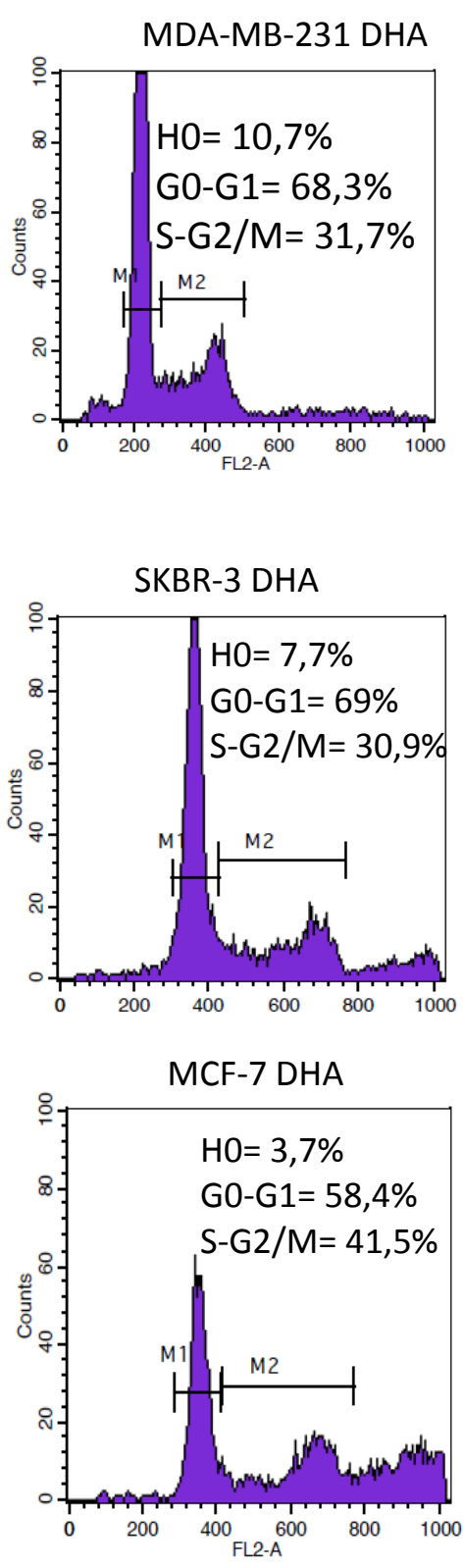

Figura 8: Histogramas (FL2A) representativos da distribuição no ciclo celular das linhagens MDA-MB-231, SKBR-3 e MCF-7. (A) EtOH: grupo controle. (B) DHA: grupo tratado; tratamento com $100 \mu \mathrm{M}$ de DHA por 72h. H0: Média dos valores que indicam a porcentagem de morte celular associada ao tratamento (pico hipodiplóide - M1). G1: Média da porcentagem de células na fase G1 do ciclo celular. S-G2/M: Média da porcentagem de células nas fases S-G2/M do ciclo celular. Os resultados são originados a partir de três diferentes ensaios em triplicata. 


\section{DISCUSSÃO}


As investigações que avaliaram os efeitos da exposição ambiental e da genética sobre o risco de desenvolver doenças buscaram, em geral, entender a relação entre a susceptibilidade à doença, exposições ambientais e mutações genéticas. Esses estudos colocaram em evidência a importância do genótipo em doenças humanas. Mais recentemente tornou-se importante incluir a interação de fatores ambientais, incluindo componentes da dieta, sobre os mecanismos epigenéticos e seu impacto na saúde e na doença [110].

Os alimentos contem compostos bioativos (CBAs), que incluem, entre vários outros, polifenóis, selênio, retinóides, ácidos graxos, isotiocianatos, e que apresentam capacidade antitumorigênica relacionada com modulação de mecanismos epigenéticos. Por interferir em eventos epigenéticos desregulados durante a carcinogênese, como a hipometilação global do DNA, hipermetilação em região promotora de genes supressores de tumor e onco-modificações em histonas, os CBAs podem modular mecanismos relevantes para a prevenção e supressão do câncer, incluindo vias de transdução de sinal, crescimento celular, diferenciação e apoptose [67].

No presente estudo, em linhagens celulares malignas (MCF-7, SKBR3 e MDA-MB-231), analisamos os efeitos do DHA sobre mecanismos epigenéticos por meio das modificações pós traducionais em histonas (H3K9ac, H4K16ac, H3K9me3 e H3K27me3) e pelo padrão de metilação na região promotora do gene RASSF1A.

O controle transitório da transcrição do gene é mediado principalmente por fatores de transcrição, enquanto que os padrões mais permanentes de expressão do gene são estabelecidos por alterações epigenéticas que incluem, entre outras, a metilação do DNA e modificações pós traducionais em histonas. A interação dinâmica entre todas essas alterações epigenéticas pode influenciar a remodelação da cromatina por ativação gênica ou silenciamento [111]. 
As modificações mais importantes em histonas, que influenciam diretamente a expressão de genes, estão localizadas nas histonas $\mathrm{H} 3 \mathrm{e}$ $\mathrm{H} 4$ [112]. A histona acetilada H3K9ac é considerada marcador de cromatina ativa e impede o silenciamento de genes, além de se correlacionar com a graduação histológica e o estadio clínico do câncer de mama [113]. $\mathrm{Na}$ presente pesquisa, o tratamento com DHA não alterou os níveis de acetilação em H3K9 de maneira universal nas três linhagens celulares mamárias malignas avaliadas, mas manifestou tendência de aumento na linhagem menos agressiva (MCF-7) e de agressividade intermediária (SKBR-3) (Figura 3). Em células MDA-MB-231, a linhagem mais agressiva em nosso estudo, a relação entre a transcrição do gene do receptor de estrógeno e acetilação em H3K9 foi estudada por Sharma e colaboradores [114]. Estes autores verificaram que a região promotora do gene de receptor de estrógeno (ER) é silenciada por hipermetilação do DNA, hipoacetilação em histonas e metilação em H3K9, resultando em linhagem que não expressa o receptor de estrógeno. Observaram ainda que o tratamento da linhagem MDA-MB-231 com inibidor de histona desacetilase $(\mathrm{HDACi})$ ou de DNMT pode reativar a expressão do mRNA do ER [114]. O equilíbrio entre a ação das enzimas acetiltransferase de histona (HAT) e histona desacetilase (HDAC) é essencial para a manutenção da função celular normal e durante a carcinogênese mamária podem ocorrer atividades aberrantes dessas enzimas [52], especialmente pela superexpressão de $\operatorname{HDAC}[11,53]$. Com isso, a inibição da atividade da HDAC tem sido considerada um potencial alvo terapêutico. Compostos bioativos dos alimentos - CBAs - podem atuar com atividade de HDACi, como o butirato, tributirina, compostos organosulfurados do alho e isotiocianatos e demonstraram capacidade de alterar acetilação em histonas e/ou atividade HDAC in vivo e in vitro [66, 115].

Observou-se, no presente trabalho, aumento significativo na acetilação em H4K16 nas linhagens MCF-7 e MDA-MB-231 (Figura 3). Esta modificação epigenética está relacionada com a reativação de expressão de genes supressores tumorais [90]. O aumento de H4K16ac tem sido relacionado com elevação de sensibilidade de células tumorais à quimioterapia e sua 
redução se correlaciona com a progressão do tumor [49, 90]. Além disso, a perda global de acetilação em H4K16 é observada simultaneamente com hipometilação global de DNA em diversos tumores malignos primários e ambas são consideradas alterações epigenéticas iniciais durante a tumorigênese [90]. Portanto, o aumento de acetilação em H4K16, na presente pesquisa, poderia sugerir mecanismo adicional do efeito antitumoral do DHA, pois diversos estudos têm descrito os efeitos do DHA na sensibilização e aumento da resposta à quimioterapia [116-118].

A trimetilação em H3K9 (H3K9me3) é marca epigenética crucial da heterocromatina e tem sido associada com a repressão da transcrição [113]. Estudos observaram correlação entre aumento de H3K9me3 e progressão de câncer, de vários tipos inclusive mama [49, 119, 120], e também com invasão e metástase tumoral [121]. Embora não tenha sido estatisticamente significante, na presente pesquisa, verificamos que o nível de H3K9me3 foi parcialmente diminuído após o tratamento com DHA, em comparação com - controle, nas linhagens celulares malignas potencialmente mais agressivas e metastáticas, como MDA-MB-231 e SKBR-3 (Figura 4). A histona H3K27me3, por sua vez, se espalha por grandes regiões que abrigam muitos genes-alvo e regula negativamente a transcrição através da promoção de uma estrutura de cromatina compacta [122]. Em câncer de mama, o nível de H3K27me3 foi relacionado como fator prognóstico e sua superexpressão parece ser dependente da expressão de EZH2 (Enhancer of Zeste Homologue 2) [123, 124].

Dimri e colaboradores relataram os efeitos dos AG $n-3$, incluindo o DHA, em modificações pós traducionais em histonas e componentes de remodelação da cromatina, em linhagens celulares de câncer de mama, MDA-MB-231. Estes autores avaliaram os níveis de EZH2, H3K27me3 e o silenciamento de genes supressores tumorais após o tratamento com $80 \mu \mathrm{M}$ de DHA por 3-8 horas [106]. Eles demonstraram diminuição da expressão da EZH2 e de H3K27me3, com consequente diminuição da capacidade invasiva dessas células [106]. Em nosso estudo, relatamos uma discreta redução dos níveis de H3K27 após o tratamento com DHA, em comparação ao controle, 
nas três linhagens celulares estudadas, MCF-7, MDA-MB-231 e SKBR-3 (Figura 4). Talvez efeitos significantes pudessem ter sido observados com exposição mais prolongada ao DHA e não em análise de 72 horas de tratamento.

O DHA pode influenciar diretamente vias de sinalização que controlam proliferação, morte celular e a expressão de genes. Esses efeitos são relacionados principalmente à capacidade do DHA em se incorporar em fosfolipídios de membrana celular $[125,126]$. O DHA pode, também, se ligar diretamente a fatores transcricionais, como a família PPAR (peroxisome proliferator-activated receptor alpha) e SREBP (sterol regulatory element binding transcription factor 2) [127, 128], e influenciar a expressão de genes que participam do ciclo celular e reparo de danos ao DNA [129]. O papel do DHA no aumento da expressão de genes supressores tumorais em câncer de mama ja foi demonstrado e inclui os genes BRCA1 e BRCA2 [36], PTEN [37], e SDC1 [130].

No presente estudo, o gene supressor tumoral estudado foi 0 RASSF1A. Este gene encontra-se frequentemente hipermetilado em região promotora, em estudos realizados in vitro e in vivo, resultando em seu silenciamento epigenético [131]. A hipermetilação na região promotora do RASSF1A está associada com prognóstico desfavorável em pacientes com câncer de mama [17, 20, 86]. Esse gene supressor tumoral codifica para uma proteína responsável pela regulação de fases do ciclo celular e apoptose. Estudos in vitro demonstraram que pouca expressão do RASSF1A está relacionado com perda de controle do ciclo celular, instabilidade genômica e resistência à apoptose [85-88].

Os dados do presente estudo revelam que o DHA promoveu aumento de expressão do gene RASSF1A na linhagem MCF-7 $(\mathrm{p}=0,03)$, mas não nas linhagens SKBR-3 e MDA-MB-231 (Figura 5). A linhagem MCF-7 é caracterizada por células epiteliais luminais, receptor de estrógeno positivas e HER-2 negativas, semelhantes aos carcinomas responsivos à hormonioterapia, e representam o fenótipo menos agressivo dentre as três 
linhagens estudadas. As células SKBR-3 são células ductais semelhantes ao carcinoma ductal invasivo do subtipo HER-2 positivo e a linhagem MDA-MB231 não expressa ER e nem HER-2, representando o subtipo triplo negativo, que apresenta marcantes características invasivas, metastáticas e tem maior potencial agressivo dentre as três linhagens. Assim, isso sugere que o DHA poderia induzir a expressão do RASSF1A em linhagens menos agressivas, indicando que sua atuação possa ser mais eficiente em estágios iniciais da carcinogênese. Adiciona-se que a inativação epigenética do RASSF1A está associada com tumores ERa+ [132, 133]. Thaler e colaboradores mostraram que o RASSF1A atua como supressor tumoral principalmente em células epiteliais ERa+, em parte, através de inibição da expressão e atividade do ERa [134].

A análise do padrão de metilação de região promotora do gene RASSF1A sugere que o DHA possa atuar em mecanimos epigenéticos, ao induzir a desmetilação de região promotora do gene RASSF1A na linhagem MCF-7 (Figura 6). Esse resultado corrobora com o aumento da expressão do gene, sugerindo que o DHA possa eventualmente estar reativando a expressão de RASSF1A nesta linhagem celular de câncer de mama. O DHA também atuou na desmetilação da região promotora do gene RASSF1A na linhagem SKBR-3, no entanto não induziu a expressão desse gene. Isso poderia sugerir que a regulação da expressão do gene RASSF1A na linhagem SKBR-3 não acontece exclusivamente por mecanismos de metilação do DNA. Além disso, não observamos nenhuma alteração na expressão e na metilação do gene RASSF1A na linhagem MDA-MB-231, o que poderia sugerir a ineficiência do DHA em modificar este gene em estádio mais avançado do câncer de mama.

O silenciamento epigenético das linhagens avaliadas na presente investigação está de acordo com os dados de Damman e colaboradores [135]. Estes autores avaliaram cinco linhagens de câncer de mama (MCF-7, MDA-MB-157, MDA-MB-231, T47D e ZR75-1) e observaram que as ithas CpG localizadas na região promotora do RASSF1A encontraram-se completamente metiladas e com sua transcrição silenciada. $O$ tratamento 
com o inibidor de metilação do DNA, 5-aza-2'-desoxicitidina, reativou a expressão do RASSF1A [135]. Nestas condições, estes autores também avaliaram os níveis de metilação do DNA no promotor do RASSF1A em tumores primários e detectaram metilação frequente nesse gene em todos os diferentes graus de carcinomas mamários. Observaram ainda inativação epigenética do RASSF1A, muito elevada, em tumores de estágio inicial, sugerindo que a metilação desse gene pode ocorrer precocemente durante a patogênese do câncer da mama [135].

Suzuki e colaboradores verificaram que a diminuição da expressão de DNMT1 mediada por RNA de interferência resultou em redução de $80 \%$ de metilação no promotor de diversos genes, incluindo o RASSF1A, com consequente reativação da expressão desse gene [136]. A superexpressão de $D N M T 3 B$ foi significativamente associada com hipermetilação em região promotora do gene RASSF1A [137].

Vários estudos demonstraram a presença de superexpressão de DNMTs (principalmente DNMT1 e DNMT3B) em câncer de mama [89, 137, 138]. A superexpressão de DNMT3B pode atingir $80 \%$ dos carcinomas mamários [138]. Simo-Riudalbas e colaboradores relataram recentemente que células de câncer de mama contêm amplificação do gene DNMT3B associado com a superexpressão do seu RNA mensageiro e proteína [139]. Em nosso estudo, não verificamos efeitos significativos na expressão de DNMT1 nas três linhagens celulares tratadas com DHA, quando comparadas ao controle (Figura 7).

Na presente investigação não foram observadas diferenças nas fases do ciclo e morte celular (Figura 8) nas linhagens celulares estudadas. No entanto, de forma distinta, a inibição do crescimento em células de câncer de mama pelos $A G n-3$, incluindo o DHA, já foi relatada em diversos estudos in vitro e in vivo [140]. Rose e Connolly, em 1990, verificaram que o DHA, e em menor extensão o EPA, inibiu o crescimento da linhagem MDA-MB-231 de maneira dose-dependente [141]. Evidências adicionais mostraram que o DHA possui atividade antiproliferativa, por deixar mais lenta a transição do 
ciclo cellular na fase G2/M [33], e também por aumentar a expressão e atividade de proteínas pró-apoptóticas como Bcl-2, caspase-8 e caspase-3 em linhagens de câncer de mama [140, 142, 143].

Para o nosso conhecimento, até o presente momento, poucos estudos avaliaram a influência do DHA em eventos epigenéticos no câncer de mama. Com base nos presentes resultados podemos afirmar que diferentes subtipos moleculares de câncer de mama respondem de maneira distinta e complexa ao tratamento com DHA. Podemos ainda sugerir novos alvos epigenéticos do DHA em linhagens de câncer de mama que ilustram a extensão dos seus efeitos. Adiciona-se que talvez efeitos mais expressivos possam ser alcançados com exposição ao DHA em longo prazo e com doses distintas. Dentre as três linhagens estudadas, a MCF-7, a menos agressiva, parece responder de maneira mais eficiente ao DHA, pois houve aumento da expressão do gene RASSF1A, tendência de desmetilação do DNA em sua região promotora, bem como o aumento da acetilação em H4K16, um ativador transcricional. Sugerimos que esses mecanismos devam ser explorados em pesquisas futuras para confirmar a ideia de que 0 efeito protetor do DHA em câncer de mama possa estar relacionado com a modulação de marcas epigenéticas, como metilação do DNA, modificação pós traducional em histonas, entre outras.

As nossas observações apresentam relevância clínica na medida em que o caráter reversível de alterações epigenéticas pode se tornar alvo para a terapia epigenética, e representar uma excelente oportunidade para 0 desenvolvimento de novas estratégias nutricionais para a prevenção e tratamento do câncer [71, 144-147]. 
7 CONCLUSÃO 
Nas condições da presente pesquisa experimental in vitro, em que linhagens de carcinoma mamário humano foram incubadas com ácido docosahexaenoico (DHA), pode-se concluir que:

1- O DHA modifica marcas epigenéticas de ativação transcricional como a acetilação em H4K16 nas linhagens MCF-7 e MDA-MB-231;

2- O DHA não atua na inibição de marcas epigenéticas associadas com repressão transcricional, como a trimetilação em H3K9 e H3K27;

3- O DHA reativa o gene supressor de tumor RASSF1A, anteriormente silenciado por hipermetilação na linhagem MCF-7;

4- O DHA altera o padrão de metilação no promotor do gene RASSF1A nas linhagens MCF-7 e SKBR-3;

5- O DHA não altera a expressão de genes que codificam as enzimas DNA metiltransferases, (DNMT1, DNMT3A e DNMT3B), nas três linhagens celulars estudadas. Entretanto, houve tendência de diminuição dos níveis de DNMT3B na linhagem MDA-MB-231. 


\section{REFERÊNCIAS}


As referências foram inseridas com a utilização do programa EndNote X3.

1. INCA, I.N.d.C. Estimativa 2012 : incidência de câncer no Brasil. 2011: Rio de Janeiro. p. 118.

2. Lee BL, et al. Breast cancer in Brazil: present status and future goals. Lancet Oncol, 2012. 13(3): p. e95-e102.

3. Beckmann MW, et al. Multistep carcinogenesis of breast cancer and tumour heterogeneity. J Mol Med (Berl), 1997. 75(6): p. 429-39.

4. Bombonati A and Sgroi DC. The molecular pathology of breast cancer progression. J Pathol, 2011. 223(2): p. 307-17.

5. Tlsty TD, et al. Genetic and epigenetic changes in mammary epithelial cells may mimic early events in carcinogenesis. J Mammary Gland Biol Neoplasia, 2004. 9(3): p. 263-74.

6. Weigelt $B$, Peterse JL, van 't Veer LJ. Breast cancer metastasis: markers and models. Nat Rev Cancer, 2005. 5(8): p. 591-602.

7. Jones PA and Baylin SB. The epigenomics of cancer. Cell, 2007. 128(4): p. 683-92.

8. Bird A. Perceptions of epigenetics. Nature, 2007. 447(7143): p. 396-8.

9. Bernstein BE, Meissner A, Lander ES. The mammalian epigenome. Cell, 2007. 128(4): p. 669-81.

10. Jenuwein T and Allis CD. Translating the histone code. Science, 2001. 293(5532): p. 1074-80.

11. Mai A and Altucci L. Epi-drugs to fight cancer: from chemistry to cancer treatment, the road ahead. Int J Biochem Cell Biol, 2009. 41(1): p. 199-213.

12. Grunstein M. Histone acetylation in chromatin structure and transcription. Nature, 1997. 389(6649): p. 349-52. 
13. Bird A. DNA methylation patterns and epigenetic memory. Genes Dev, 2002. 16(1): p. 6-21.

14. Herceg $Z$ and Hainaut P. Genetic and epigenetic alterations as biomarkers for cancer detection, diagnosis and prognosis. Mol Oncol, 2007. 1(1): p. 26-41.

15. Lewis $\mathrm{CM}$, et al. Promoter hypermethylation in benign breast epithelium in relation to predicted breast cancer risk. Clin Cancer Res, 2005. 11(1): p. 166-72.

16. Dworkin AM, Huang $\mathrm{TH}$ and Toland AE. Epigenetic alterations in the breast: Implications for breast cancer detection, prognosis and treatment. Semin Cancer Biol, 2009. 19(3): p. 165-71.

17. Pfeifer GP and Dammann R. Methylation of the tumor suppressor gene RASSF1A in human tumors. Biochemistry (Mosc), 2005. 70(5): p. 576-83.

18. Jiang $\mathrm{Y}$, et al. The prognostic role of RASSF1A promoter methylation in breast cancer: a meta-analysis of published data. PLoS One, 2012. 7(5): p. e36780.

19. Muller HM, et al. Prognostic DNA methylation marker in serum of cancer patients. Ann N Y Acad Sci, 2004. 1022: p. 44-9.

20. Yeo $\mathrm{W}$, et al. High frequency of promoter hypermethylation of RASSF1A in tumorous and non-tumourous tissue of breast cancer. Pathology, 2005. 37(2): p. 125-30.

21. Gerber M. Omega-3 fatty acids and cancers: a systematic update review of epidemiological studies. Br J Nutr, 2012. 107 Suppl 2: p. S228-39.

22. Rose DP, Connolly JM, ColemanM. Effect of omega-3 fatty acids on the progression of metastases after the surgical excision of human breast cancer cell solid tumors growing in nude mice. Clin Cancer Res, 1996. 2(10): p. 1751-6.

23. Noguchi $M$, et al. Chemoprevention of DMBA-induced mammary carcinogenesis in rats by low-dose EPA and DHA. Br J Cancer, 1997. 75(3): p. 348-53. 
24. Rose DP and Connolly JM. Omega-3 fatty acids as cancer chemopreventive agents. Pharmacol Ther, 1999. 83(3): p. 217-44.

25. Signori C, et al. Chemoprevention of breast cancer by fish oil in preclinical models: trials and tribulations. Cancer Res, 2011. 71(19): p. 6091-6.

26. Bartram HP, et al. Effects of fish oil on rectal cell proliferation, mucosal fatty acids, and prostaglandin E2 release in healthy subjects. Gastroenterology, 1993. 105(5): p. 1317-22.

27. Hardman WE. Omega-3 fatty acids to augment cancer therapy. J Nutr, 2002. 132(11 Suppl): p. 3508S-3512S.

28. Bagga $D$, et al. Long-chain n-3-to-n-6 polyunsaturated fatty acid ratios in breast adipose tissue from women with and without breast cancer. Nutr Cancer, 2002. 42(2): p. 180-5.

29. Wu M, et al. Omega-3 polyunsaturated fatty acids attenuate breast cancer growth through activation of a neutral sphingomyelinasemediated pathway. Int J Cancer, 2005. 117(3): p. 340-8.

30. Das UN and Madhavi N. Effect of polyunsaturated fatty acids on drugsensitive and resistant tumor cells in vitro. Lipids Health Dis, 2011. 10: p. 159.

31. Sun $\mathrm{H}$, et al. Omega-3 fatty acids induce apoptosis in human breast cancer cells and mouse mammary tissue through syndecan-1 inhibition of the MEK-Erk pathway. Carcinogenesis, 2011. 32(10): p. 1518-24.

32. Schley PD, Brindley DN, Field CJ. (n-3) PUFA alter raft lipid composition and decrease epidermal growth factor receptor levels in lipid rafts of human breast cancer cells. J Nutr, 2007. 137(3): p. 548-53.

33. Barascu A, et al. CDK1-cyclin B1 mediates the inhibition of proliferation induced by omega-3 fatty acids in MDA-MB-231 breast cancer cells. Int J Biochem Cell Biol, 2006. 38(2): p. 196-208.

34. Siddiqui RA, et al. Docosahexaenoic acid: a natural powerful adjuvant that improves efficacy for anticancer treatment with no adverse effects. Biofactors, 2011. 37(6): p. 399-412. 
35. Ravacci GR, et al. Lipid raft disruption by docosahexaenoic acid induces apoptosis in transformed human mammary luminal epithelial cells harboring HER-2 overexpression. J Nutr Biochem, 2012.

36. Bernard-Gallon DJ, et al. Differential effects of $n-3$ and $n-6$ polyunsaturated fatty acids on BRCA1 and BRCA2 gene expression in breast cell lines. Br J Nutr, 2002. 87(4): p. 281-9.

37. Ghosh-Choudhury T, et al. Fish oil targets PTEN to regulate NFkappaB for downregulation of anti-apoptotic genes in breast tumor growth. Breast Cancer Res Treat, 2009. 118(1): p. 213-28.

38. Sandoval $\mathrm{J}$ and Esteller M. Cancer epigenomics: beyond genomics. Curr Opin Genet Dev, 2012. 22(1): p. 50-5.

39. Yoo CB and Jones PA. Epigenetic therapy of cancer: past, present and future. Nat Rev Drug Discov, 2006. 5(1): p. 37-50.

40. Sharma S, Kelly TK, Jones PA. Epigenetics in cancer. Carcinogenesis, 2010. 31(1): p. 27-36.

41. Worm $\mathrm{J}$ and Guldberg P. DNA methylation: an epigenetic pathway to cancer and a promising target for anticancer therapy. J Oral Pathol Med, 2002. 31(8): p. 443-9.

42. Rodenhiser D and Mann M. Epigenetics and human disease: translating basic biology into clinical applications. CMAJ, 2006. 174(3): p. 341-8.

43. Strahl BD and AllisCD. The language of covalent histone modifications. Nature, 2000. 403(6765): p. 41-5.

44. Turner BM. Reading signals on the nucleosome with a new nomenclature for modified histones. Nat Struct Mol Biol, 2005. 12(2): p. 110-2.

45. Waterland RA and Michels KB. Epigenetic epidemiology of the developmental origins hypothesis. Annu Rev Nutr, 2007. 27: p. 363-88.

46. Steinmann K, et al. Frequent promoter hypermethylation of tumorrelated genes in head and neck squamous cell carcinoma. Oncol Rep, 2009. 22(6): p. 1519-1526. 
47. Fischle $\mathrm{W}$, Wang $\mathrm{Y}$ and Allis CD. Histone and chromatin cross-talk. Curr Opin Cell Biol, 2003. 15(2): p. 172-83.

48. Kouzarides T. Chromatin modifications and their function. Cell, 2007. 128(4): p. 693-705.

49. Elsheikh SE, et al. Global histone modifications in breast cancer correlate with tumor phenotypes, prognostic factors, and patient outcome. Cancer Res, 2009. 69(9): p. 3802-9.

50. Mai A, et al. Histone deacetylation in epigenetics: an attractive target for anticancer therapy. Med Res Rev, 2005. 25(3): p. 261-309.

51. Ross SA and Milner JA. Epigenetic modulation and cancer: effect of metabolic syndrome? Am J Clin Nutr, 2007. 86(3): p. s872-7.

52. Esteller M. Cancer epigenomics: DNA methylomes and histonemodification maps. Nat Rev Genet, 2007. 8(4): p. 286-98.

53. Minucci $S$ and Pelicci PG. Histone deacetylase inhibitors and the promise of epigenetic (and more) treatments for cancer. Nat Rev Cancer, 2006. 6(1): p. 38-51.

54. Kelly WK, O'Connor OA and Marks PA. Histone deacetylase inhibitors: from target to clinical trials. Expert Opin Investig Drugs, 2002. 11(12): p. 1695-713.

55. Qian DZ, et al. Targeting tumor angiogenesis with histone deacetylase inhibitors: the hydroxamic acid derivative LBH589. Clin Cancer Res, 2006. 12(2): p. 634-42.

56. Kim YI. Nutritional epigenetics: impact of folate deficiency on DNA methylation and colon cancer susceptibility. J Nutr, 2005. 135(11): p. 2703-9.

57. Szyf M. The DNA methylation machinery as a therapeutic target. Curr Drug Targets, 2000. 1(1): p. 101-18.

58. Esteller $\mathrm{M}$, et al. A gene hypermethylation profile of human cancer. Cancer Res, 2001. 61(8): p. 3225-9.

59. Franco $R$, et al. Oxidative stress, DNA methylation and carcinogenesis. Cancer Lett, 2008. 266(1): p. 6-11. 
60. Herceg Z. Epigenetics and cancer: towards an evaluation of the impact of environmental and dietary factors. Mutagenesis, 2007. 22(2): p. 91-103.

61. Agrawal A, Murphy RF and Agrawal DK. DNA methylation in breast and colorectal cancers. Mod Pathol, 2007. 20(7): p. 711-21.

62. Romaguera D, et al. Is concordance with World Cancer Research Fund/American Institute for Cancer Research guidelines for cancer prevention related to subsequent risk of cancer? Results from the EPIC study. Am J Clin Nutr, 2012. 96(1): p. 150-63.

63. Doll $R$ and Peto $R$. The causes of cancer: quantitative estimates of avoidable risks of cancer in the United States today. J Natl Cancer Inst, 1981. 66(6): p. 1191-308.

64. Wiseman M. The second World Cancer Research Fund/American Institute for Cancer Research expert report. Food, nutrition, physical activity, and the prevention of cancer: a global perspective. Proc Nutr Soc, 2008. 67(3): p. 253-6.

65. Kushi LH, et al. American Cancer Society Guidelines on nutrition and physical activity for cancer prevention: reducing the risk of cancer with healthy food choices and physical activity. CA Cancer J Clin, 2012. 62(1): p. 30-67.

66. Delage $\mathrm{B}$ and Dashwood $\mathrm{RH}$. Dietary manipulation of histone structure and function. Annu Rev Nutr, 2008. 28: p. 347-66.

67. Ong TP, Moreno FS and Ross SA. Targeting the epigenome with bioactive food components for cancer prevention. J Nutrigenet Nutrigenomics, 2012. 4(5): p. 275-92.

68. Ross SA. Diet and DNA methylation interactions in cancer prevention. Ann N Y Acad Sci, 2003. 983: p. 197-207.

69. Davis CD and Uthus EO. DNA methylation, cancer susceptibility, and nutrient interactions. Exp Biol Med (Maywood), 2004. 229(10): p. 988-95.

70. McCabe DC and Caudill MA. DNA methylation, genomic silencing, and links to nutrition and cancer. Nutr Rev, 2005. 63(6 Pt 1): p. 183-95. 
71. Zeisel SH. Epigenetic mechanisms for nutrition determinants of later health outcomes. Am J Clin Nutr, 2009. 89(5): p. 1488S-1493S.

72. Hauser AT and Jung M. Targeting epigenetic mechanisms: potential of natural products in cancer chemoprevention. Planta Med, 2008. 74(13): p. 1593-601.

73. Fang $\mathrm{MZ}$, et al. Tea polyphenol (-)-epigallocatechin-3-gallate inhibits DNA methyltransferase and reactivates methylation-silenced genes in cancer cell lines. Cancer Res, 2003. 63(22): p. 7563-70.

74. Dashwood $\mathrm{RH}$ and Ho E. Dietary histone deacetylase inhibitors: from cells to mice to man. Semin Cancer Biol, 2007. 17(5): p. 363-9.

75. Ferlay J, et al. Estimates of worldwide burden of cancer in 2008: GLOBOCAN 2008. Int J Cancer. 127(12): p. 2893-917.

76. Veronesi U, et al. Breast cancer. Lancet, 2005. 365(9472): p. 1727-41.

77. Perou CM, et al. Molecular portraits of human breast tumours. Nature, 2000. 406(6797): p. 747-52.

78. Huang $\mathrm{Y}$, et al. Epigenetics in breast cancer: what's new? Breast Cancer Res, 2012. 13(6): p. 225.

79. Wilson AS, Power BE and Molloy PL. DNA hypomethylation and human diseases. Biochim Biophys Acta, 2007. 1775(1): p. 138-62.

80. Veeck $\mathrm{J}$ and Esteller M. Breast cancer epigenetics: from DNA methylation to microRNAs. J Mammary Gland Biol Neoplasia, 2010. 15(1): p. 5-17.

81. Bae YK, et al. Hypermethylation in histologically distinct classes of breast cancer. Clin Cancer Res, 2004. 10(18 Pt 1): p. 5998-6005.

82. Wei M, et al. Estrogen receptor alpha, BRCA1, and FANCF promoter methylation occur in distinct subsets of sporadic breast cancers. Breast Cancer Res Treat, 2008. 111(1): p. 113-20.

83. Fiegl $\mathrm{H}$, et al. Breast cancer DNA methylation profiles in cancer cells and tumor stroma: association with HER-2/neu status in primary breast cancer. Cancer Res, 2006. 66(1): p. 29-33. 
84. Agathanggelou A, Cooper WN and Latif F. Role of the Ras-association domain family 1 tumor suppressor gene in human cancers. Cancer Res, 2005. 65(9): p. 3497-508.

85. Baksh S, et al. The tumor suppressor RASSF1A and MAP-1 link death receptor signaling to Bax conformational change and cell death. Mol Cell, 2005. 18(6): p. 637-50.

86. Dallol A, et al. Involvement of the RASSF1A tumor suppressor gene in controlling cell migration. Cancer Res, 2005. 65(17): p. 7653-9.

87. Vos MD, et al. The RASSF1A tumor suppressor activates Bax via MOAP-1. J Biol Chem, 2006. 281(8): p. 4557-63.

88. Donninger $\mathrm{H}$, Vos MD, and Clark GJ. The RASSF1A tumor suppressor. J Cell Sci, 2007. 120(Pt 18): p. 3163-72.

89. Girault I, et al. Expression analysis of DNA methyltransferases 1, 3A, and 3B in sporadic breast carcinomas. Clin Cancer Res, 2003. 9(12): p. $4415-22$.

90. Fraga MF, et al. Loss of acetylation at Lys16 and trimethylation at Lys20 of histone $\mathrm{H} 4$ is a common hallmark of human cancer. Nat Genet, 2005. 37(4): p. 391-400.

91. Gunstone FD, et al. The lipid handbook 3ed. 2007, London: Taylor \& Francis Group, LLC. 656.

92. Tvrzicka E, et al. Fatty acids as biocompounds: their role in human metabolism, health and disease--a review. Part 1: classification, dietary sources and biological functions. Biomed Pap Med Fac Univ Palacky Olomouc Czech Repub. 155(2): p. 117-30.

93. Simopoulos AP. Evolutionary aspects of omega-3 fatty acids in the food supply. Prostaglandins Leukot Essent Fatty Acids, 1999. 60(5-6): p. 421-9.

94. Simopoulos AP. Omega-3 fatty acids in health and disease and in growth and development. Am J Clin Nutr, 1991. 54(3): p. 438-63.

95. Simopoulos A.P. The importance of the omega-6/omega-3 fatty acid ratio in cardiovascular disease and other chronic diseases. Exp Biol Med (Maywood), 2008. 233(6): p. 674-88. 
96. Waitzberg DL, Torrinhas RS and Jacintho TM. New parenteral lipid emulsions for clinical use. JPEN J Parenter Enteral Nutr, 2006. 30(4): p. 351-67.

97. Pawlosky RJ, et al. Physiological compartmental analysis of alphalinolenic acid metabolism in adult humans. J Lipid Res, 2001. 42(8): p. 1257-65.

98. Kaizer $L$, et al. Fish consumption and breast cancer risk: an ecological study. Nutr Cancer, 1989. 12(1): p. 61-8.

99. Schley PD, et al. Mechanisms of omega-3 fatty acid-induced growth inhibition in MDA-MB-231 human breast cancer cells. Breast Cancer Res Treat, 2005. 92(2): p. 187-95.

100. Fernanda Cury-Boaventura $\mathrm{M}$, et al. Mechanisms involved in Jurkat cell death induced by oleic and linoleic acids. Clin Nutr, 2006. 25(6): p. 1004-14.

101. Menendez JA, et al. HER2 (erbB-2)-targeted effects of the omega-3 polyunsaturated fatty acid, alpha-linolenic acid (ALA; 18:3n-3), in breast cancer cells: the "fat features" of the "Mediterranean diet" as an "anti-HER2 cocktail". Clin Trans/ Oncol, 2006. 8(11): p. 812-20.

102. Biondo PD, et al. The potential for treatment with dietary long-chain polyunsaturated n-3 fatty acids during chemotherapy. J Nutr Biochem, 2008. 19(12): p. 787-96.

103. Duncan RE, El-Sohemy A and Archer MC. Regulation of HMG-CoA reductase in MCF-7 cells by genistein, EPA, and DHA, alone and in combination with mevastatin. Cancer Lett, 2005. 224(2): p. 221-8.

104. Hammamieh $\mathrm{R}$, et al. Differential effects of omega-3 and omega-6 Fatty acids on gene expression in breast cancer cells. Breast Cancer Res Treat, 2007. 101(1): p. 7-16.

105. Almeida DF, et al. Docosahexaenoic acid regulates genes related with lipid metabolism differently in normal and breast cancer cell line: A microarray approach. J Nutrigenet Nutrigenomics, 2012(5): p. 171302 (217-218). 
106. Dimri $\mathrm{M}$, et al. Dietary omega-3 polyunsaturated fatty acids suppress expression of EZH2 in breast cancer cells. Carcinogenesis, 2011. 31(3): p. 489-95.

107. Nohara K, Wang F and Spiegel F. Glycosphingolipid composition of MDA-MB-231 and MCF-7 human breast cancer cell lines. Breast Cancer Res Treat, 1998. 48(2): p. 149-57.

108. Livak KJ and Schmittgen TD. Analysis of relative gene expression data using real-time quantitative PCR and the 2(-Delta Delta $\mathrm{C}(\mathrm{T})$ ) Method. Methods, 2001. 25(4): p. 402-8.

109. Burbee DG, et al. Epigenetic inactivation of RASSF1A in lung and breast cancers and malignant phenotype suppression. J Natl Cancer Inst, 2001. 93(9): p. 691-9.

110. Jirtle $R L$ and Skinner MK. Environmental epigenomics and disease susceptibility. Nat Rev Genet, 2007. 8(4): p. 253-62.

111. Gronbaek K, et al. Epigenetic changes in cancer as potential targets for prophylaxis and maintenance therapy. Basic Clin Pharmacol Toxicol, 2008. 103(5): p. 389-96.

112. Bronner $\mathrm{C}$, et al. UHRF1 Links the Histone code and DNA Methylation to ensure Faithful Epigenetic Memory Inheritance. Genet Epigenet, 2010. 2009(2): p. 29-36.

113. Fullgrabe J, Kavanagh E and Joseph B. Histone onco-modifications. Oncogene, 2011. 30(31): p. 3391-403.

114. Sharma D, et al. Release of methyl CpG binding proteins and histone deacetylase 1 from the Estrogen receptor alpha (ER) promoter upon reactivation in ER-negative human breast cancer cells. Mol Endocrinol, 2005. 19(7): p. 1740-51.

115. de Conti A, et al. Chemopreventive effects of the dietary histone deacetylase inhibitor tributyrin alone or in combination with vitamin A during the promotion phase of rat hepatocarcinogenesis. $J$ Nutr Biochem, 2012. 23(8): p. 860-6.

116. Hajjaji $N$ and Bougnoux $P$. Selective sensitization of tumors to chemotherapy by marine-derived lipids: A review. Cancer Treat Rev, 2013. 39(5): p. 473-88. 
117. Colas S, et al. Sensitization by dietary docosahexaenoic acid of rat mammary carcinoma to anthracycline: a role for tumor vascularization. Clin Cancer Res, 2006. 12(19): p. 5879-86.

118. Bougnoux $\mathrm{P}$, et al. Improving outcome of chemotherapy of metastatic breast cancer by docosahexaenoic acid: a phase II trial. $\mathrm{Br} \mathrm{J}$ Cancer, 2009. 101(12): p. 1978-85.

119. Park YS, et al. The global histone modification pattern correlates with cancer recurrence and overall survival in gastric adenocarcinoma. Ann Surg Oncol, 2008. 15(7): p. 1968-76.

120. Nguyen CT, et al. Histone H3-lysine 9 methylation is associated with aberrant gene silencing in cancer cells and is rapidly reversed by 5 aza-2'-deoxycytidine. Cancer Res, 2002. 62(22): p. 6456-61.

121. Yokoyama $\mathrm{Y}$, et al. Cancer-associated upregulation of histone $\mathrm{H} 3$ lysine 9 trimethylation promotes cell motility in vitro and drives tumor formation in vivo. Cancer Sci, 2013.

122. Ringrose $\mathrm{L}$, Ehret $\mathrm{H}$ and Paro R. Distinct contributions of histone $\mathrm{H} 3$ lysine 9 and 27 methylation to locus-specific stability of polycomb complexes. Mol Cell, 2004. 16(4): p. 641-53.

123. Wei $\mathrm{Y}$, et al. Loss of trimethylation at lysine 27 of histone $\mathrm{H} 3$ is a predictor of poor outcome in breast, ovarian, and pancreatic cancers. Mol Carcinog, 2008. 47(9): p. 701-6.

124. Hansen $\mathrm{KH}$, et al. A model for transmission of the H3K27me3 epigenetic mark. Nat Cell Biol, 2008. 10(11): p. 1291-300.

125. Rogers KR, et al. Docosahexaenoic acid alters epidermal growth factor receptor-related signaling by disrupting its lipid raft association. Carcinogenesis. 31(9): p. 1523-30.

126. Corsetto PA, et al. Effects of n-3 PUFAs on breast cancer cells through their incorporation in plasma membrane. Lipids Health Dis. 10: p. 73.

127. Altenburg JD, et al. A synergistic antiproliferation effect of curcumin and docosahexaenoic acid in SK-BR-3 breast cancer cells: unique signaling not explained by the effects of either compound alone. BMC Cancer. 11: p. 149. 
128. Kaur G, et al. Docosapentaenoic acid (22:5n-3) down-regulates the expression of genes involved in fat synthesis in liver cells. Prostaglandins Leukot Essent Fatty Acids. 85(3-4): p. 155-61.

129. Chiu LC, Wong EY and Ooi VE. Docosahexaenoic acid modulates different genes in cell cycle and apoptosis to control growth of human leukemia HL-60 cells. Int J Oncol, 2004. 25(3): p. 737-44.

130. Sun $\mathrm{H}$, Berquin IM and Edwards IJ. Omega-3 polyunsaturated fatty acids regulate syndecan-1 expression in human breast cancer cells. Cancer Res, 2005. 65(10): p. 4442-7.

131. van der Weyden $L$ and Adams DJ. The Ras-association domain family (RASSF) members and their role in human tumourigenesis. Biochim Biophys Acta, 2007. 1776(1): p. 58-85.

132. Sunami E, et al. Estrogen receptor and HER2/neu status affect epigenetic differences of tumor-related genes in primary breast tumors. Breast Cancer Res, 2008. 10(3): p. R46.

133. Feng $\mathrm{W}$, et al. Correlation between $\mathrm{CpG}$ methylation profiles and hormone receptor status in breast cancers. Breast Cancer Res, 2007. 9(4): p. R57.

134. Thaler S, et al. RASSF1A inhibits estrogen receptor alpha expression and estrogen-independent signalling: implications for breast cancer development. Oncogene, 2012. 31(47): p. 4912-22.

135. Dammann R, Yang $G$ and Pfeifer GP. Hypermethylation of the $c p G$ island of Ras association domain family 1A (RASSF1A), a putative tumor suppressor gene from the 3p21.3 locus, occurs in a large percentage of human breast cancers. Cancer Res, 2001. 61(7): p. 3105-9.

136. Suzuki $M$, et al. RNA interference-mediated knockdown of DNA methyltransferase 1 leads to promoter demethylation and gene reexpression in human lung and breast cancer cells. Cancer Res, 2004. 64(9): p. 3137-43.

137. Ben Gacem R, et al. Clinicopathologic significance of DNA methyltransferase $1,3 \mathrm{a}$, and $3 \mathrm{~b}$ overexpression in Tunisian breast cancers. Hum Pathol, 2012. 43(10): p. 1731-8. 
138. Butcher DT and Rodenhiser DI. Epigenetic inactivation of BRCA1 is associated with aberrant expression of CTCF and DNA methyltransferase (DNMT3B) in some sporadic breast tumours. Eur $J$ Cancer, 2007. 43(1): p. 210-9.

139. Simo-Riudalbas L, Melo SA and Esteller M. DNMT3B gene amplification predicts resistance to DNA demethylating drugs. Genes Chromosomes Cancer, 2011. 50(7): p. 527-34.

140. Chamras $\mathrm{H}$, et al. Fatty acid modulation of MCF-7 human breast cancer cell proliferation, apoptosis and differentiation. J Nutr Biochem, 2002. 13(12): p. 711-716.

141. Rose DP and Connolly JM. Effects of fatty acids and inhibitors of eicosanoid synthesis on the growth of a human breast cancer cell line in culture. Cancer Res, 1990. 50(22): p. 7139-44.

142. Blanckaert $\mathrm{V}$, et al. Docosahexaenoic acid intake decreases proliferation, increases apoptosis and decreases the invasive potential of the human breast carcinoma cell line MDA-MB-231. Int $J$ Oncol, 2010. 36(3): p. 737-42.

143. Corsetto PA, et al. Effects of n-3 PUFAs on breast cancer cells through their incorporation in plasma membrane. Lipids Health Dis, 2011. 10: p. 73.

144. Sigalotti L, et al. Epigenetic drugs as pleiotropic agents in cancer treatment: biomolecular aspects and clinical applications. J Cell Physiol, 2007. 212(2): p. 330-44.

145. Mathers JC. Session 2: Personalised nutrition. Epigenomics: a basis for understanding individual differences? Proc Nutr Soc, 2008. 67(4): p. 390-4.

146. Balch C, et al. New anti-cancer strategies: epigenetic therapies and biomarkers. Front Biosci, 2005. 10: p. 1897-931.

147. Yang CS, et al. Reversal of hypermethylation and reactivation of genes by dietary polyphenolic compounds. Nutr Rev, 2008. 66 Suppl 1: p. S18-20. 